\title{
PEDAGOGÍA DE LOS MÁRTIRES, COMUNIDADES MILI- TANTES CATÓLICAS Y TERRITORIO: EL CASO DE LA ISLA MACIEL, BUENOS AIRES, ARGENTINA(2016-2019).
}

PEDAGOGY OF THE MARTYRS, CATHOLIC MILITANT COMMUNITIES AND TERRITORY: THE CASE OF ISLA MACIEL, BUENOS AIRES ARGENTINA (2016-2019).

PÉDAGOGIE DES MARTYRS, COMMUNAUTÉS MILITANTES CATHOLIQUES ET TERRITOIRE: LE CAS D'ISLA MACIEL, BUENOS AIRES, ARGENTINE (2016-2019).

PEDAGOGIA DOS MÁRTIRES, COMUNIDADES MILITANTES CATÓLICAS E TERRITÓRIO: O CASO DA ISLA MACIEL, BUENOS AIRES, ARGENTINA (2016-2019).

Leonel Salomón Tribilsi ${ }^{*}$ https://orcid.org/0000-0002-5890-4104

RESUMEN: El presente artículo propone analizar algunos aspectos de las dinámicas del activismo religioso católico en un barrio marginal del Área Metropolitana de Buenos Aires, la isla Maciel, en la actualidad (2016-2019). Se busca comprender cómo allí se ponen en funcionamiento prácticas pedagógicas hilvanadas en torno a las figuras de los mártires del catolicismo, es decir, sacerdotes, religiosos/as y obispos que fueron objeto de la represión estatal durante la última dictadura militar (1976-1983) y que han conformado un canon memorial en la posdictadura. Se abordarán dos dimensiones, por un lado, el repertorio de símbolos, imágenes, murales, slogans que marcan el territorio de la parroquia y sus anexos a los fines de contribuir a la comprensión de la construcción de comunidades militantes en los barrios populares. Por el otro, las redes de activismo social, político y humanitario que se tejen más allá de las fronteras territoriales. Por último, se problematizarán las tensiones que surgen de estas dinámicas, poniendo en evidencia los límites del repertorio pedagógico.

Palabras clave: Activismo católico; víctimas del terrorismo

\footnotetext{
* Licenciado en Sociología; Doctorando en Ciencias Sociales por la Universidad de Buenos Aires (UBA); Becario del Centro de Estudios y Investigaciones Laborales (CEIL) del Consejo Nacional de Investigaciones Científicas y Técnicas (CONICET), Buenos Aires, Argentina; e-mail: tribilsi@gmail.com
} 
Pedagogía de los mártires, comunidades militantes católicas y territorio: el caso de la Isla Maciel, Buenos Aires, Argentina (2016-2019).

de Estado; mártires; barrios marginales; prácticas pedagógicas.

ABSTRACT: This article proposes to analyze some aspects of the dynamics of Catholic religious activism in a marginal neighborhood of the Metropolitan Area of Buenos Aires, Isla Maciel, at present (2016-2019). We seek to understand how pedagogical practices are put into practice around the figures of the martyrs of $\mathrm{Ca}$ tholicism, that is, priests, religious and bishops who were the object of state repression during the last military dictatorship and who have formed a memorial canon in the post-dictatorship (1976-1983). We will work two dimensions, on the one hand, the repertoire of symbols, images, murals, slogans that mark the territory of the parish and its annexes in order to contribute to the understanding of the construction of militant communities in popular neighborhoods. On the other, the networks of social, political and humanitarian activism that are woven beyond the territorial borders. Finally, we will problematize the tensions that arise from these dynamics, highlighting the limits of the pedagogical repertoire.

Keywords: Catholic activism; victims of State terrorism; martyrs; marginal neighborhoods; pedagogical practices.

RÉSUMÉ: Cet article propose d'analyser certains aspects des dynamiques de l'activisme religieux catholique dans un quartier marginal en banlieue sud de la région métropolitaine de Buenos Aires, l'île Maciel (2016-2019). Dans ce cadre, nous cherchons à comprendre comment les pratiques pédagogiques sont mises en pratique autour des figures des martyrs du catholicisme, c'est-à-dire des prêtres, des religieux et des évêques qui ont été l'objet de la répression étatique, lors de la dernière dictature militaire (19761983) et qui ont formé un canon commémoratif dans la post-dictature. Nous travaillerons dans deux aspects, d'une part, le répertoire des symboles, des images, des peintures murales, des slogans graffités qui marquent le territoire de la paroisse et ses annexes, afin de contribuer à la compréhension de la construction de communautés militantes dans des quartiers populaires. De l'autre, les réseaux d'activisme social, politique et humanitaire qui s'étendent au-delà des frontières territoriales. Enfin, nous allons soulever la problématique des tensions issues de ces dynamiques en soulignant les limites de ce répertoire pédagogique.

Mots clés: Activisme catholique; victimes du terrorisme d'Etat; martyrs; Quartiers marginaux; pratiques pédagogiques.

RESUMO: Este artigo propõe analisar alguns aspectos da 
dinâmica do ativismo religioso católico num bairro marginal da área metropolitana de Buenos Aires, Isla Maciel, na atualidade (2016-2019). Buscamos compreender como as práticas pedagógicas são operadas em relação com as figuras dos mártires do catolicismo, ou seja, sacerdotes, religiosos/as e bispos que foram objeto de repressão durante a última ditadura militar (1976-1983) e formaram um cânon memorial na pós-ditadura. Trabalharemos duas dimensões, por um lado, o repertório de símbolos, imagens, pintura mural, slogans que marcam o território da paróquia e seus anexos, a fim de contribuir para a compreensão da construção de comunidades militantes nas vilas da periferia. Por outro lado, as redes de ativismo social, politico e humanitário que são criadas além dessas fronteiras territoriais. Por fim, problematizaremos as tensões que surgem dessas dinâmicas, evidenciando os limites desse repertório pedagógico.

Palavras chave: Ativismo católico; vítimas do terrorismo de Estado; mártires; bairros marginais; práticas pedagógicas.

\section{INTRODUCCIÓN}

Diversos estudios han planteado la importancia de las memorias de las víctimas del terrorismo de Estado en el Cono Sur de América Latina para impulsar nuevas formas de activismo en democracia (Vecchioli y Martinelli Leal, 2017). Trabajos como el de Dominella (2013) han focalizado en los procesos de rememoración de víctimas católicas en comunidades locales, y otros abordajes, como el de Catoggio (2016a) han indagado sobre la productividad de la "memoria de los mártires", es decir, del clero contestatario víctima del terrorismo de Estado, para procesar el pasado traumático y dar sentido a nuevas causas en el presente. En ese marco, este trabajo se propone analizar la relación entre el activismo clerical, los usos pedagógicos de la figura del mártir para construir comunidades militantes y redes de activismo en derechos humanos, así como sus límites a la hora de pronunciarse en la arena pública. El caso escogido es el de la parroquia Nuestra Señora de Fátima ubicada en la Isla Maciel, en el partido de Avellaneda, durante la administración del sacerdote Francisco Olveira entre el 2016 y el 2018. Como se verá, en torno a esa parroquia se construyó una "comunidad militante" que abarca otros dispositivos institucionales del mismo barrio por 
Pedagogía de los mártires, comunidades militantes católicas y territorio: el caso de la Isla Maciel, Buenos Aires, Argentina (2016-2019).

los cuales circulan los mismos actores (Giménez Béliveau, 2016). El nexo más importante para su conformación fue la presencia y actividad del sacerdote Olveira, conocido públicamente como el "padre Paco" y miembro del grupo de Curas en Opción por los Pobres. Para comprender esta configuración militante, en los primeros apartados de este artículo se hará foco en los usos y en las dinámicas comunitarias que se construyeron en torno a las figuras del catolicismo consideradas mártires del terrorismo de Estado. Desde una recorrida por los espacios locales, se tomará nota de los soportes materiales de esas figuras y se analizará su rol pedagógico en la identificación comunitaria. Seguidamente, se observarán los modos en que esas mismas figuras son puestas en movimiento en actos y conmemoraciones que, además, orientan la vinculación de la comunidad con actores sociales externos, en particular, con agentes de la arena política y del entramado de activismos por los derechos humanos. Por último, se abordará cómo el recurso a la "memoria de los mártires" vehicula distintos tipos de posicionamientos políticos y eclesiásticos evidenciando tensiones en distintas esferas de acción social, mostrando así los alcances y límites de dicho repertorio en la arena pública.

El trabajo se vale del análisis de un corpus de materiales relevados entre agosto de 2016 y marzo de 2019, mediante una serie de estrategias teórico-metodológicas propias de la investigación cualitativa. El mismo se comprende de cuatro entrevistas en profundidad realizadas a diferentes colaboradoras y colaboradores de la parroquia Nuestra Señora de Fátima, y una quinta mantenida con el sacerdote Francisco "Paco" Olveira. Las primeras se realizaron a diversas integrantes de la comunidad parroquial y de la Fundación Isla Maciel quienes, con el propósito de mantener su confidencialidad, serán mencionadas de acuerdo a uno de sus roles: ministra de la eucaristía, trabajadora social, profesional y catequista. A su vez, se tomó registro de las actividades del grupo mediante la técnica de observación participante y a través de comunicaciones informales con sus referentes, tanto en el territorio como por fuera del mismo, en diversos formatos: notas de campo, fotografías, grabaciones, recopilación de material escrito, etc. Espacialmente, el trabajo de campo se centró en la actividad realizada en la parroquia Nuestra Señora de 
Fátima, en el convento Nuestra Señora de Fátima, en la Fundación Isla Maciel, y en la parroquia Beato Óscar Romero, todos sitos en el barrio. Ocasionalmente se relevaron también actividades en otros sitios en los que miembros de la comunidad participaron activamente. Con el propósito de reconocer las dinámicas y los entramados sociales de la parroquia y su contexto barrial o vecinal, se optó por la adopción del paradigma interpretativo procurando comprender el carácter construido de los significados que los actores le atribuyen a las interacciones del mundo social observado (Vasilachis, 2006).

\section{LOS SUCESOS PÓSTUMOS COMO PUNTO DE PARTIDA/ LLEGADA}

Finalizando el proceso de redacción del presente artículo (a comienzos del 2019) se desencadenaron una serie de hechos en el campo de investigación cuya relevancia obliga a que, al menos de un modo incipiente, sean mencionados y tomados en cuenta como un punto de partida o, si se quiere, de llegada. Dado el carácter reciente de los mismos y siendo que aún continúan desarrollándose, las interpretaciones sobre ellos serán provisorias $\mathrm{y}$, en todo caso, sugerentes de futuros trabajos.

El 15 de febrero del 2019 un grupo de miembros y ex catequistas de la comunidad parroquial de la Isla Maciel (esto es, el grupo sobre el cual versa este artículo) emitió un comunicado denunciando varias actitudes del sacerdote Mario Ghisaura, el nuevo párroco designado por el obispo, quien sustituyó al sacerdote Francisco "Paco" Olveira desde enero (Uranga, 2019). Uno de los principales reproches que allí le hacen a Ghisaura tiene que ver con la decisión unilateral del sacerdote de bajar los cuadros de los mártires (figuras del catolicismo local que fueron víctimas de la represión dictatorial) y borrar algunos murales internos de la parroquia y del convento. Además, denunciaron que Ghisaura omite referirse a una de las parroquias del barrio por su nuevo nombre "Beato Óscar Romero" (uno de esos mártires) y propone una vuelta al pasado con el de "Nuestra Señora de Itatí”. ¿Por qué estos actos son tan significativos? ¿Por qué 
Pedagogía de los mártires, comunidades militantes católicas y territorio: el caso de la Isla Maciel, Buenos Aires, Argentina (2016-2019).

algunas modificaciones que podrían catalogarse como meramente decorativas del espacio parroquial han de crispar los nervios de la feligresía y han de ser interpretadas como provocaciones? ¿Qué pudo significar el cambio de párroco y porqué resultan centrales las figuras o los nombres de esos mártires del catolicismo? Algunas claves para comenzar a responder estos interrogantes pueden obtenerse analizando la forma de construcción comunitaria que se produjo en la Isla Maciel durante la gestión del sacerdote Olveira. Allí, como se verá a continuación, las figuras de los mártires del catolicismo han ocupado un lugar privilegiado y han tenido una carga de sentido muy particular. Pero es necesario remontarse aún más atrás en el tiempo para una cabal comprensión de esa carga.

\section{EL CATOLICISMO EN EL "MUNDO DE LOS POBRES" Y LA "MEMORIA DE LOS MÁRTIRES"}

La presencia del catolicismo en el "mundo de los pobres" tiene antecedentes que se remontan a la puja situada a comienzos del siglo pasado entre el modelo de nación liberal, el emergente socialismo y la llamada utopía del catolicismo integral, que buscaba la ocupación de todos los espacios sociales (Mallimaci, 1992), en la disputa por encarnar el lugar natural de la argentinidad (Zanatta, 1996). Aun cuando desde finales del siglo xx se viene observando una doble dinámica de ruptura del monopolio católico y de pluralización del campo religioso (Mallimaci y Giménez Béliveau, 2007), la presencia y centralidad histórica del catolicismo sigue siendo incuestionable. Aun en tensión con otros imaginarios, el catolicismo ha logrado mantener la predominancia en la disputa por su presencia en las esferas públicas. Por otro lado, es preciso manifestar el también histórico carácter heterogéneo del catolicismo en la Argentina:

Estudiar el catolicismo en la Argentina supone enfrentarse a un objeto complejo, vital y cambiante, cuyos recortes y definiciones son plurales [...] el catolicismo es concebido como un espacio social en disputa, en el que grupos y personas proponen visiones convergentes o encontradas de los fines últimos de sus acciones, de la defini- 
ción de sus pautas identitarias, de los límites de las pertenencias, de la forma misma y de los alcances del catolicismo. (Giménez Béliveau, 2016, p.19)

Esta historicidad del catolicismo en la Argentina se puede recorrer en paralelo a una trayectoria específica con respecto a su relación con el llamado "mundo de los pobres". Así, como describe Catoggio, es posible notar tempranamente que, en aquellas disputas de principios del siglo xx enfrentando al modelo liberal vigente, "el catolicismo hizo suya como forma de impugnación al orden la demanda por la inclusión de pobres, mujeres, indígenas, entre otros marginados por el modelo económico y político en boga" (2013, p.247). El proceso simbiótico de asimilación de la argentinidad al catolicismo estuvo ligado a la preocupación por la cuestión social. En este decurso, los acontecimientos sociopolíticos del continente, desencadenados con el triunfo de la revolución cubana en 1959, marcaron un salto cualitativo. Desde entonces y de un modo sincrónico, otras experiencias, como la Guerra del Vietnam o los procesos de descolonización en África, han sido recíprocamente influyentes con la gestación de imaginarios culturales de ruptura y expectativas revolucionarias en el continente.

El difundido imperativo del cambio estimulado por el Concilio Vaticano II (1962-1965), la Conferencia Episcopal Latinoamericana de Medellín (1968) o la Conferencia de San Miguel en Argentina (1969), entre otros, fragmentó las posiciones al interior del catolicismo local entre los sectores más reacios al mismo y aquellos que, aun heterogéneamente, decidieron "optar por los pobres". Este proceso permitió una significativa modificación con respecto a la concepción del pobre que dejó de ser objeto de caridad y asistencia para convertirse en sujeto de transformación social (Löwy, 1999). De manera consecuente al Concilio Vaticano II y a la corriente intelectual conocida como la teología de la liberación surgieron en Latinoamérica diversas manifestaciones de aquello que Michael Löwy (op. cit.) denominó como cristianismo liberacionista. En el caso argentino, surgen o se renuevan experiencias como la de los Curas Obreros, las agrupaciones juveniles católicas o la revista Cristianis- 
Pedagogía de los mártires, comunidades militantes católicas y territorio: el caso de la Isla Maciel, Buenos Aires, Argentina (2016-2019).

mo y Revolución. En estos círculos "liberacionistas", el Movimiento de Sacerdotes para el Tercer Mundo (MSTM) es referenciado como el espacio de condensación de estas tendencias de cambio, en torno a la cual se trazaron redes sociales más amplias donde interactuaron personas provenientes de diversos ámbitos socio políticos (Donatello, 2005; Martín, 2010; Touris, 2008). El compromiso político de los adherentes a estas vertientes del catolicismo y las tareas realizadas en torno a las llamadas comunidades de base implicaron la interacción y sociabilidad con actores provenientes de otras trayectorias de militancia y activismo, muchas veces relacionadas a las expresiones políticas de izquierda y al movimiento peronista en donde también hallaba asidero la crítica a la violación estructural de los derechos inherente al modelo socioeconómico vigente (Donatello, 2010; Mayol, Habegger y Armada, 1970; Obregón, 2005). El acercamiento a las bases en los sectores populares constituyó un elemento fundamental para la militancia de estos actores que comenzaron a experimentar diversas formas de vinculación con los sujetos considerados agentes del cambio social aproximándose a sus espacios vitales.

Los caminos a seguir cubrieron un amplio arco de posibilidades, uno de cuyos extremos era cierto tipo de destinatarios (los jóvenes, los indígenas, los obreros, los trabajadores rurales, entre otros) y el otro era un tipo de lugar social (el barrio marginal, la villa, la comunidad, la fábrica, la cooperativa rural). En el límite, algunos pocos consideraron que la liberación de los pobres exigía el camino de la lucha armada. (Catoggio, 2013, p.252)

En esta etapa destacaron algunas personalidades que serán centrales en relación a esta forma de acción social vinculada al mundo religioso. En ciertos casos el reconocimiento llegó de la mano de su trágico desenlace por el accionar represivo de la última dictadura militar. Valiéndose, entre otros mecanismos, de la construcción del imaginario social de la "subversión", las Fuerzas Armadas persiguieron a un amplio segmento de la sociedad que actuaba "por fuera de los márgenes del orden prescrito". La etapa en sí, como proceso histórico, ha sido conceptualizada como "un proceso social genoci- 
da" atendiendo a la sistematicidad de las violaciones a los derechos humanos y el grupo social que fue objeto del terrorismo de Estado. Retomando las palabras de Feierstein, "la experiencia de aniquilamiento no fue dirigida contra un grupo de víctimas acotado, sino que se trató de un proceso político que operó sobre el pueblo argentino, transformando sus modos hegemónicos de relación social" (Feierstein, 2006, p.31). Si bien abundante literatura académica ha consignado y denunciado la connivencia del clero católico con el accionar represivo, también se ha destacado la presencia de los actores religiosos en las filas de las víctimas. Estos análisis van desde la proposición de la existencia de dos iglesias, una opresora y la otra perseguida (Dri, 1986; Mignone 1999), hasta estudios más complejos sobre las diferentes estrategias de supervivencia en los entramados sociales en que se vinculan lo religioso, lo militar y lo estatal (Catoggio, 2016a).

Si bien el MSTM se disolvió en 1973, antes de dicha experiencia trágica, la referencia a este movimiento fue recuperada como sello identitario por otras agrupaciones que se consideraron sus herederas. Una de ellas es el grupo de los Curas Villeros, caracterizado por vivir y llevar adelante su labor pastoral en los barrios pobres. Esta forma de practicar el sacerdocio fue iniciada en la década de 1960 por algunos curas, entre ellos Carlos Mugica. El actual equipo, que forma la llamada "pastoral villera" se formalizó en 1998 y en el 2009, por iniciativa del entonces cardenal Jorge Bergoglio, adquirió el rango de vicaría. Su principal figura es el sacerdote José María Di Paola y su campo de acción son los barrios marginales de la ciudad de Buenos Aires y algunos sectores del Conurbano (Premat, 2010; Prieto y Lotito, 2012). El grupo de Curas en Opción Por los Pobres es otra de estas agrupaciones. Se creó en 1986 tras un reencuentro de sacerdotes pertenecientes al MSTM y, sin tomar la estructura de un movimiento, aglutinó a varios sacerdotes de todo el país, muchos de ellos también residentes de barrios carenciados (Arias, 2016; Barral, 2016). Ambos grupos se reúnen periódicamente y suelen emitir comunicados públicos con críticas sociales y políticas con diferentes niveles de vehemencia. Al igual que los religiosos asesinados por su compromiso social, y a los cuales consideran como mártires, pro- 
Pedagogía de los mártires, comunidades militantes católicas y territorio: el caso de la Isla Maciel, Buenos Aires, Argentina (2016-2019).

curan realizar el trabajo con los pobres en sus espacios vitales. Asimismo, los miembros del grupo de Curas en Opción por los Pobres, además de criticar y combatir las injusticias y desigualdades que produce el modelo socioeconómico, se suman a las denuncias por los crímenes del terrorismo de Estado que en muchos casos los acercan a espacios de militancia por la memoria y por losderechos humanos.

Como se verá en este artículo, la rememoración de determinadas figuras del catolicismo que son consideradas mártires, resulta nodal para el trabajo de las nuevas experiencias que se perciben herederas de su legado. Así, en el caso de la parroquia de la Isla Maciel, bajo la administración del sacerdote Francisco Olveira, quien pertenece al grupo de Curas en Opción Por los Pobres, el recurso a dichas figuras legitima la forma de realizar la labor social a la vez que permite confrontar un modelo de sociedad y catolicismo con sectores más conservadores. Siguiendo a Catoggio (2016a) resulta interesante observar cómo se va conformando lo se puede designar como un canon de las figuras elegidas para ocupar ese rol orientador e interpretar qué tipo de discursos y acción legitiman. En esta línea, lo novedoso de este análisis son los usos pedagógicos de esta memoria de los mártires para construir una comunidad militante en los barrios pobres, como la Isla Maciel, para articular redes más amplias de activismos en el campo de los derechos humanos y para asumir distintos pronunciamientos políticos tanto en el seno de la institución como en la arena pública.

\section{USOS PEDAGÓGICOS Y MARCAS TERRITORIALES: LOS MURALES Y LAS CONSIGNAS EN EL ESPACIO PARRO- QUIAL-BARRIAL}

Las figuras de los mártires en el territorio se presentan principalmente en soportes materiales: fotografías, cuadros, láminas, afiches, pinturas y murales. A partir de su examen se intentará, no solo reconstruir el linaje que mantienen con la tradición del cristianismo liberacionista, sino también pensar de qué manera las memorias funcionan en la construcción del presente. Según Daniéle Hervieu-Léger toda religión implica una movilización específica de la memoria 
colectiva, memoria que es redefinida constantemente, revitalizada a través del rito, y la cual favorece la identificación del grupo en relación a la continuidad de un linaje creyente (Hervieu-Léger, 2005). El concepto de memoria colectiva remite no a la sumatoria de las capacidades individuales de recordar, sino a los procesos por los cuales los grupos van redefiniendo, en tiempo presente y no sin pujas, los marcos, reforzados con rituales y conmemoraciones, mediante los cuales es posible recuperar los acontecimientos pasados (Halbwachs, 2004; Jelin, 2002). Partiendo de los estudios de la memoria como fenómeno social, el concepto de los "vectores de memoria", en tanto "canales de transmisión" y/o "soportes del relato" resulta oportuno ya que permite reconocer, por un lado, la forma en que se cristaliza la lucha contra el avance del tiempo, y del tiempo social, cuya naturaleza es cambiante, y por el otro lado, el carácter colectivo de esas manifestaciones de la memoria que "tienen la función de estructurar la identidad del grupo" (Rousso, 2012, p.5) y que, además, van a ser objeto de disputas (Ricoeur, 2000; Valensi, 1998). La recorrida por el territorio va a permitir distinguir la presencia de objetos que pueden ser vistos como vectores, sostenes de una memoria que va siendo construida. A las figuras allí presentes se las dota, en la práctica, de un carisma específico, el martirio o la victimización heroica por cuya continuidad se lucha en la actualidad.

Las imágenes más difundidas en los espacios de la constelación de la parroquia Nuestra Señora de Fátima son, a la par que las imágenes consagradas de la Virgen María y las de Jesucristo, las de las y los religiosos que han sido víctimas del terrorismo de Estado. Entre ellos se encuentran el sacerdote Carlos Mugica, el obispo Enrique Angelelli y el salvadoreño Óscar Romero. Tanto Mugica como Angelelli adhirieron explícitamente al catolicismo post conciliar y a su "opción por los pobres". Mugica, que perteneció al MTSM y abrazó al peronismo, fue asesinado en 1974 por las fuerzas represivas, y Angelelli murió en 1976 en un accidente automovilístico considerado un atentado perpetrado por dichas fuerzas. Si bien Romero fue obispo en El Salvador, su historia posee varios puntos en común con los argentinos, siendo asesinado en 1980 por el terrorismo de Estado salvadoreño, luego de haber denunciado los abusos del po- 
Pedagogía de los mártires, comunidades militantes católicas y territorio: el caso de la Isla Maciel, Buenos Aires, Argentina (2016-2019).

der. Presentes de muchas maneras, sus rostros o sus frases célebres se lucen en fotografías, en afiches, o en murales, y algunas salas, e incluso una capilla, llevan sus nombres. También se observan otros actores en menor medida: los miembros de la comunidad palotina asesinados en la "Masacre de San Patricio" y las "monjas francesas" Alice Domon y Léonie Duquet. Los primeros fueron los sacerdotes Alfredo Leaden, Pedro Duffau, y Alberto Kelly, y los seminaristas Salvador Barbeito y Emilio Barletti; todos ellos asesinados el 4 de julio de 1976 en la parroquia de San Patricio. Domon y Duquet fueron secuestradas, desaparecidas y asesinadas en 1977. Todos ellos son religiosos que, tras haber realizado actividades de denuncia o resistencia frente a los gobiernos autoritarios, fueron asesinados por las fuerzas represivas. La conformación de este panteón es el resultado de la cristalización de procesos sociales de legitimación de este conjunto. Siguiendo a Catoggio, los sacerdotes Angelelli y Mugica contaron en vida con un cierto prestigio y carisma en relación a su labor religiosa: "conformaron un repertorio simbólico de modelos ejemplificadores [que se] reforzó y adquirió rasgos de canon con [su] desenlace trágico" (2016a, p.226). Los "palotinos" también se convirtieron rápidamente en íconos de la persecución religiosa, con el agregado de la condición de "víctimas inocentes" que les fue adjudicada socialmente (Catoggio, 2016a, p.232), de un modo similar al caso de las "monjas francesas".

Este conjunto seleccionado no innova con respecto a los casos que calaron hondo en el imaginario colectivo, como puede observarse en la invocación de su memoria en innumerables homenajes, incluso a nivel estatal. A modo de simplificación de la exposición, en el presente artículo se mencionará al canon de mártires para hacer referencia al grupo conformado por las figuras de Mugica, Angelelli, Romero, los "palotinos" y las "monjas francesas", que son usadas con mayor frecuencia en los ámbitos parroquiales estudiados. Eventualmente, este canon se flexibiliza incluye a otros religiosos. 


\section{LA LLEGADA DEL SACERDOTE FRANCISCO "PACO" OLVEIRA A LA ISLA MACIEL}

La marcación del espacio con las figuras del canon responde a una doble finalidad, de rememoración, por un lado, y de identificación grupal, por el otro. Para ello, es necesario considerar tanto la centralidad de la figura del sacerdote Olveira como las dinámicas mediante las cuales se relaciona la parroquia con el barrio. Olveira, que ha sido el administrador parroquial de Nuestra Señora de Fátima desde el año 2005 hasta el 2018, es parte del grupo de Curas en Opción Por los Pobres y, además de las tareas religiosas, motoriza diversas actividades sociales principalmente desde la Fundación Isla Maciel, institución que preside. Nacido en España y formado allí como sacerdote de la Iglesia Católica, es asimismo enfermero y abogado. Suele además tener una relativa presencia en diversos actos públicos por causas políticas que lo han acercado a figuras del peronismo kirchnerista y a reconocidos militantes por los derechos humanos. Con frecuencia es entrevistado por diversos medios de comunicación encarnado la postura del grupo de Curas en Opción Por los Pobres denunciando la desigualdad social del país, especialmente a partir del giro neoliberal que supuso la presidencia de Mauricio Macri. Con su llegada al barrio y a la parroquia se iniciaron una serie de transformaciones, entre ellas la marcación del espacio con las figuras del canon, orientadas a los modos de concebir y llevar a cabo la práctica religiosa:

Cuando llegamos hacía un año y medio que el cura había muerto, el cura era muy mayor, el cura era capellán de la policía bonaerense, el cura tenía muy mal genio y estaba todo, digamos, no había prácticamente nada. [...] Años y años no se había utilizado la cancha de fútbol, la única actividad que había era la catequesis los domingos a la mañana, y que era todavía una catequesis de pregunta y respuesta, el chico tenía “¿Quién es Dios?” y tenía que memorizar, "Dios es nuestro padre que está en los cielos, creador y señor de todas las cosas que premia lo bueno y castiga lo malo", [...] eran noventa y nueve preguntas. [...] Lo primero que hice fue pasarme más o menos seis meses sacando mugre y ordenando. Lo que hoy nosotros le llamamos la sacristía estaba llena de cosas, pero tan llena de cosas que 
Pedagogía de los mártires, comunidades militantes católicas y territorio: el caso de la Isla Maciel, Buenos Aires, Argentina (2016-2019).

no podías entrar. Para entrar tuve que entrar de costado, empezar a sacar cosas que había ido acumulando el cura durante un montón, montón de años. (Entrevista a Francisco Olveira, El revolucionario bar, cuidad de Buenos Aires, 29 de mayo de 2017).

Es importante remarcar la distinción de Olveira con respecto al cura Leopoldo Subaukar, el sacerdote que lo precedió en la Isla Maciel, ya que permite contemplar por contraste la relevancia de su llegada. A lo largo del tiempo, el sacerdote ha revitalizado diferentes ámbitos institucionales que, a su vez, generaron un creciente protagonismo de la institución religiosa en la vida comunitaria de la Isla Maciel, y, complementariamente, una mayor participación de los vecinos en la misma. Sus principales dispositivos son las capillas Nuestra Señora de Fátima y Beato Óscar Romero, la Fundación Isla Maciel y el convento Nuestra Señora de Fátima. Como se irá viendo, en todos estos espacios aparecen elementos que tienen la impronta de Olveira y del grupo de Curas en Opción Por los Pobres; elementos que interpelan al observador sugiriéndole una determinada forma de catolicismo que se halla inserto en la comunidad barrial y que asume el compromiso social como una prioridad.

Estos cambios permitieron que algunas personas resignifiquen su compromiso con la iglesia abandonando actitudes previas de distanciamiento o de indiferencia:

Yo siempre fui rebelde con respecto a la iglesia. Producto de mi imagen de iglesia conservadora, todo relacionado con la culpa y el pecado. Nunca tuve intención de ser monja, ni nada del estilo. [...] Yo puteaba a la iglesia y a los papas rodeados en oro que no les importa nada los pobres. Por otro lado, la jerarquía había tenido un papel nefasto en la dictadura militar argentina. [...] Y yo creo que en mí también, aunque dormido, tapado por el papel que había jugado la Iglesia en la dictadura, por esa Iglesia que yo conocía que era conservadora, superficial, más vinculada al parecer que al ser, que eso un poco había aplastado mi fe profunda. A medida que me fui entrelazando mucho más con los sectores más populares, eso volvió a renacer en mí. [...] Él [el sacerdote Francisco Olveira] hace 12 años que está en la Isla. Y una se enamora del trabajo que hace, porque vos ves ahí la verdadera palabra de Jesús llevada a la práctica por 
un hombre, en este caso "Paco". (Entrevista a Profesional, Plaza de Mayo, ciudad de Buenos Aires, 13 de abril de 2017).

Siempre fui a la iglesia de la Isla Maciel, en ese momento estaba Leopoldo [Subaukar], hice mi bautismo, mi comunión, la confirmación, eran misas vacías para mi gusto, una iglesia muy tradicional, yo me tenía que confesar con él, le tenía que decir mis pecados y un montón de cosas más y creo que eso me limitó como persona, yo no tenía mucha vida adolescente, no me juntaba con las pibas en la esquina, no la viví tan a pleno como los chicos la viven hoy, siempre estaba muy "ay, diosito esto, diosito lo otro". Estaba de acuerdo con eso. Me alejé mucho tiempo de la iglesia, solo iba por obligación de mi mamá, porque había que acompañarla, entonces decidí alejarme porque no me sentía cómoda. Decidí retirarme de esa práctica cristiana. Después de mucho tiempo comencé a acercarme por Francisco [Olveira] a la Iglesia y cambió mi visión, también la facultad me hizo tener otra visión de la realidad, porque ya tenía una óptica cientista o cientificista y muchas de las cosas dependían de la acción del hombre y no dependían de la fe. (Entrevista a Trabajadora Social, Luján, 11 de diciembre de 2016).

Si bien estas dos entrevistadas presentan trayectorias disímiles, permiten observar la versatilidad del grupo. La profesional, de 64 años, tiene una vasta recorrida militante y su distanciamiento y posterior reencantamiento con la iglesia está definido por el carisma personal de "Paco" y por el sentido de pertenencia que encuentra en la comunidad militante construida en torno a la parroquia. Si bien no nació ni vive en la Isla Maciel, forma parte de su comunidad y es conocedora del grupo de Curas en Opción Por los Pobres y su labor social, elementos determinantes en su decisión de colaborar. La Trabajadora Social, de 36 años, ha nacido y vivido en el barrio, y conoció al párroco anterior, Leopoldo Subaukar. Su alejamiento está relacionado, entre otras cosas, a su insatisfacción en la adolescencia. $\mathrm{Y}$ su regreso tiene que ver con el estilo sacerdotal de Olveira que le permite conciliar la práctica social con sus aprendizajes académicos. Estos dos casos no saturan todo el abanico de posibilidades pero sí permiten captar esa versatilidad del grupo. De igual manera, las figuras de los mártires van a significar, para una, el corolario de una amplia trayectoria con experiencias relacionadas a esa corriente 
Pedagogía de los mártires, comunidades militantes católicas y territorio: el caso de la Isla Maciel, Buenos Aires, Argentina (2016-2019).

del catolicismo y, para la otra, la posibilidad de una nueva forma de practicar la religión, compatible con sus expectativas sobre el trabajo social llevado a la práctica.

\section{LA PARROQUIA NUESTRA SEÑORA DE FÁTIMA}

Posando la mirada en la parroquia Nuestra Señora de Fátima es posible trabajar con el modo en que ciertos objetos de la misma sugieren una determinada construcción identitaria que conjuga lo religioso con las problemáticas sociales del entorno barrial. Éste ámbito es el espacio litúrgico principal donde se celebran las ceremonias religiosas como la "santa misa". En su decoración interna combina elementos más tradicionales de la simbología católica, como ser las imágenes devocionales de los santos o de la Virgen María, con elementos menos ortodoxos, como las banderas de los países latinoamericanos o el colorido mural en el ábside (Imagen 1). 


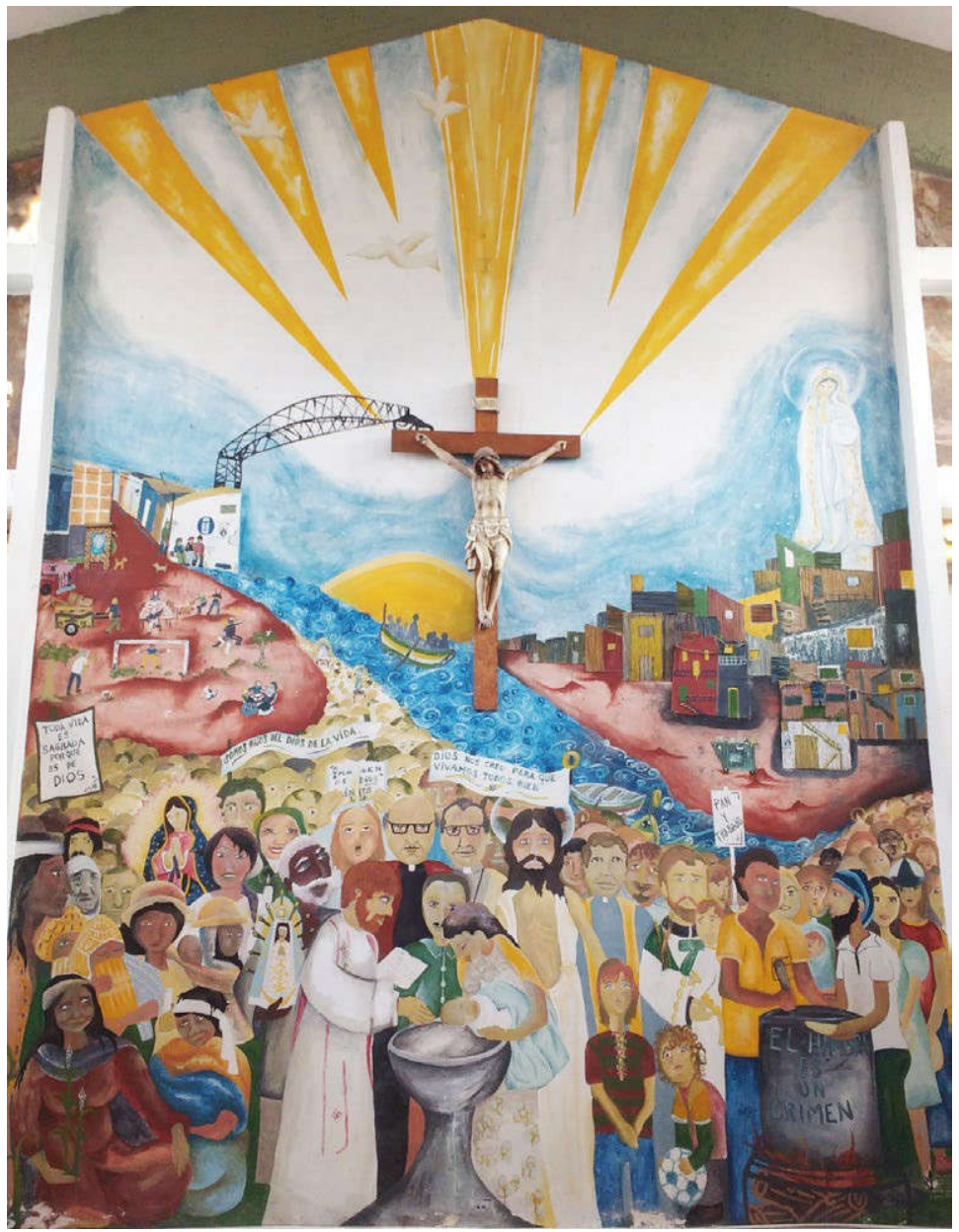

1. Mural en el ábside de la parroquia Nuestra Señora de Fátima, Isla Maciel, Avellaneda. Fotografía propia, 19 de mayo de 2017.

Su estilo remite mucho más a las corrientes del muralismo 
latinoamericano ${ }^{1}$ que al estilo tradicional del mural religioso en iglesias. Sin analizar la dimensión estética del mismo, lo cual no es objeto de este trabajo, es posible reflexionar sobre sus significados. En la escena representada se alza un crucifijo con la imagen de Jesucristo emplazado en el territorio de la Isla Maciel (representado icónicamente por el puente que lo une al barrio La Boca o la barca que atraviesa el Riachuelo, entre otros). Más abajo se reitera la imagen de Jesucristo, ya no crucificado sino caminando junto a una multitud y a varios sacerdotes. Este grupo alza panfletos con consignas entre las cuales se lee "Pan y Trabajo" o "Dios nos creó para que vivamos todos bien". Resulta evidente la referencia a la icónica obra de Antonio Berni, Manifestación (1934), en donde una multitud también sostiene una pancarta que dice "Pan y Trabajo". Asimismo, esa obra de Berni alude a una previa obra clásica de Ernesto de la Cárcova, Sin pan y sin trabajo (1894). El mural de la parroquia retoma las mismas preocupaciones sociales que los clásicos plasmaron en sus obras y las ensambla con los motivos del liberacionismo católico. Este ejercicio de articulación de imágenes de la tradición autorizada del catolicismo (como Jesús y la Virgen María) con consignas y frases que guían -dirigiendo- el sentido de la historia de salvación enhebrada con la historia humana, forma parte de una praxis típica del cristianismo liberacionista descripto por Löwy para los años sesenta y sesenta. La figura de Jesucristo aparece dotada de vitalidad (a sus espaldas brilla un sol magnificente) acompañado por varios sacerdotes, cuyos rasgos aluden a los de los mártires antes mencionados, y junto a un nutrido grupo de personas que representa a la comunidad barrial (niños, jóvenes, ancianos, madres amamantando, personas con rasgos e indumentaria de los pueblos originarios, etc.). El conjunto avanza alegremente mientras reclama por sus derechos. Esta escena sugiere un tipo de realización que parte de lo colectivo, siguiendo el modelo pedagógico de los mártires y el acervo másam-

1 La experiencia del movimiento muralista mexicano a principios del siglo $\mathrm{xx}$ es una referencia ineludible especialmente por su identificación con las luchas revolucionarias y su concepción como arte social, político y pedagógico. David Alfaro Siqueiros, uno de sus principales exponentes declaraba, en un manifiesto firmado colectivamente, que "el arte del pueblo de México es la manifestación espiritual más grande y más sana del mundo y su tradición indígena es la mejor de todas. $\mathrm{Y}$ es grande precisamente porque siendo popular es colectiva, y es por eso que nuestro objetivo fundamental radica en socializar las manifestaciones artísticas tendiendo hacia la desaparición absoluta del individualismo por burgués" (Siqueiros et al. 1923). 
plio de experiencias del cristianismo liberacionista. Coronando esta acción, se puede leer a ambos lados del mural la frase "bajemos a los pobres de la cruz". Esta expresión remite a una forma de comprensión de lo religioso en términos materialistas que discute con orientaciones más tradicionales y/o meramente espirituales. Con ello se critica a los argumentos religiosos que limitan el cambio social ofreciendo como compensación al sufrimiento en el mundo terrenal una salvación en el mundo venidero (tras la muerte) bajo la imagen del paraíso. "Bajar a los pobres de la cruz" implica entonces trabajar concreta y materialmente para reducir y/o terminar su sufrimiento. Como se verá más adelante, estas presentaciones tienen también un carácter pedagógico que es posible destacar.

Siguiendo la recorrida por la parroquia, se observa otro elemento sugerente. Nuevamente combinando aspectos tradicionales con marcas más distintivas, se halla una réplica de la Virgen de Luján ${ }^{2}$ investida con la bandera de los pueblos originarios, la bandera argentina y una fotografía del papa Francisco junto a la dirigente social Milagro Sala, considerada una presa política del gobierno nacional y por quien se reclama su liberación. Impensados en la "época de Leopoldo [Subaukar]" -como expresan las entrevistadas refiriéndose al pasado parroquial-, estos objetos continúan en la línea que integra los aspectos de la simbología religiosa con las referencias a las luchas socio políticas de la realidad actual. Esta combinación presenta cierta osadía en tanto conjuga elementos indiscutidos de la devoción católica, como la Virgen de Lujan y la figura del papa Francisco con elementos más polémicos como la bandera de los pueblos originarios o la imagen de Milagro Sala, poniendo de manifiesto el apoyo a sus causas. Esta combinatoria, orientada a la feligresía barrial, supone un trabajo sobre las identidades uniendo los símbolos de la creencia con los de las reivindicaciones políticas acerca de las condiciones materiales de existencia.

2 La Virgen de Luján, o Nuestra Señora de Luján, es considerada la patrona de la Argentina, Uruguay y Paraguay y la estatua con su imagen, realizada a mediados del siglo xvii se encuentra en la basílica de Luján, el templo católico que es considerado el Santuario Nacional de laArgentina. 
Pedagogía de los mártires, comunidades militantes católicas y territorio: el caso de la Isla Maciel, Buenos Aires, Argentina (2016-2019).

\section{EL CONVENTO NUESTRA SEÑORA DE FÁTIMA}

En el convento Nuestra Señora de Fátima, otro espacio administrado por el sacerdote Olveira, es posible notar de qué manera la presencia de determinados objetos se vincula con la penetración de la institución religiosa en la vida más general del barrio. El lugar en sí, que es mucho más grande que la parroquia (ocupa más de media manzana), dispone de aulas, oficinas de administración, espacios deportivos, depósitos de herramientas, donaciones y alimentos, biblioteca, cocina y parrilla. Es un área de reunión mucho más frecuentada que la parroquia. En primer lugar, por su mayor extensión y equipamiento, que permiten la realización de diversas actividades en paralelo o eventos y celebraciones más concurridas. Así, cotidianamente funcionan diversas actividades entre las que destaca el comedor infantil que acoge a un significativo número de niños. En segundo lugar, por estar ubicado sobre una calle principal del barrio, donde circulan los servicios de transporte público, con lo cual el acceso es mucho más sencillo.

Aquí es posible hallar otra significativa cantidad de elementos que representan al canon de mártires y a otras figuraciones religiosas e, incluso, políticas, plasmados en la materialidad de los espacios comunes (paredes, puertas, adornos, etc.). Hay, por ejemplo, varios afiches con fotos de Carlos Mugica o de Enrique Angelelli junto a algunas de sus frases como "creo que la misión del sacerdote es evangelizar a los pobres e interpelar a los ricos”. Incluso las salas están nominadas con sus nombres. También se halla otra estatua con la imagen de la Virgen María junto con una foto de la dirigente social Milagro Sala y la leyenda "liberen a Milagro". Un colorido mural grafica a Jesucristo recién nacido en una cuna junto a las figuras de María y José que exigen "la dignidad de su Qunita [sic]" para cada bebé, aludiendo al Plan Qunitas, que le otorgaba a las madres un kit de maternidad por medio del sistema de salud pública, el cual fue promulgado durante el kirchnerismo y discontinuado en la gestión de Mauricio Macri.

Estas alusiones perfilan una doble tendencia, por un lado, dar a entender que las actividades de la institución exceden lo meramente religioso o litúrgico, y por el otro, se refuerza la intención de mancomunar al barrio al elegir elementos que son parte de la cotidianei500| Século XXI, Revista de Ciências Sociais, v.9, nº 2, p.481-527, jul./dez. 2019 
dad y de las preocupaciones de sus habitantes. Esta iglesia se ofrece, de esta manera, como un portavoz legítimo para los reclamos de la gente del barrio. El sentido de territorialidad es un elemento fundamental para esta proposición. La ubicación del convento en la geografía de la zona le permite articular con diversos espacios sociales y dispositivos estatales, como la unidad sanitaria, la escuela, el jardín de infantes, el Centro de Prevención de Adicciones o el proyecto FinEs, entre otros. ${ }^{3}$

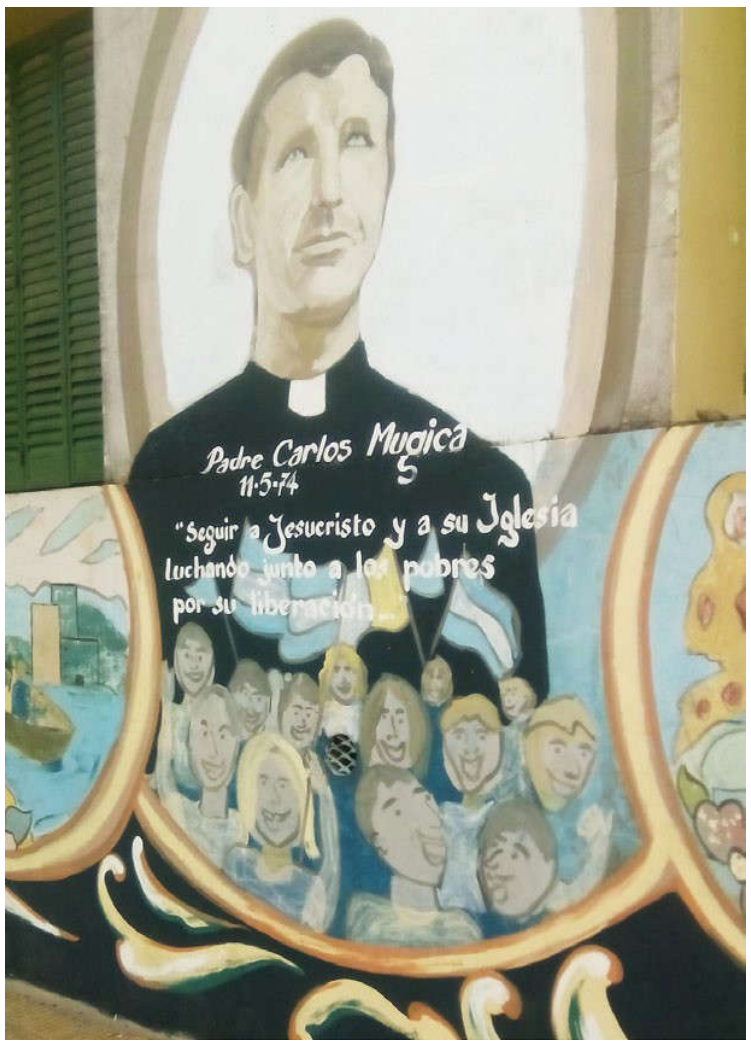

2. Mural del padre Carlos Mugica realizado por el Grupo Cultural Cruz del Sur en el convento Nuestra Señora de Fátima, Isla Maciel, Avellaneda. Fotografía propia, 2 de diciembre de 2016.

3 Sobre las relaciones entre los dispositivos institucionales entre la iglesia católica y el Estado argentino es posible consultar, entre otros, a Giménez Béliveau (2016) y a Mallimaci(1992).

501 | Século XXI, Revista de Ciências Sociais, v.9, n² 2, p.481-527, jul./dez. 2019 
Pedagogía de los mártires, comunidades militantes católicas y territorio: el caso de la Isla Maciel, Buenos Aires, Argentina (2016-2019).

En esta arena también aparecen las figuras de los mártires, orientadas ahora a generar visibilidad y caracterización del grupo en el barrio, complementando la construcción de la identidad comunitaria. En las paredes externas del convento hay murales que conmemoran a los mártires "palotinos", a Carlos Mugica (Imagen 2), a Enrique Angelelli, a Óscar Romero, a Alice Domon y a Leonie Duquet; es decir, al canon completo. Y están acompañadas de sugerentes frases que les pertenecen: "seguir a Jesucristo y a su iglesia luchando junto a los pobres por su liberación" (Mugica), "callarse hoy sería cobarde, sería la muerte" (Duquet), "un oído en el pueblo y otro en el evangelio" (Angelelli), "si me matan resucitaré en el pueblo" (Romero), entre otras. A su vez, cada figura tiene inscripta una fecha, la de su asesinato o desaparición forzada, resaltando así su carácter martirológico. Este habitar el espacio público consolida la centralidad de la institución religiosa para la vida barrial proponiéndose además como un portavoz válido para la negociación y articulación entre las necesidades de esa población y el Estado. En términos de marcación ${ }^{4}$, el recurso nuevamente del muralismo y su contenido, permiten la visibilidad pública de una corriente específica de catolicismo. Entonces, el espacio religioso que se erige en la centralidad del entramado barrial promueve públicamente el reconocimiento de las figuras mártires con las cuales se identifica y a través de las cuales vectoriza su propia forma católica de proceder.

\section{ELEMENTOS PEDAGÓGICOS DE LA CATEQUESIS}

Otro elemento significativo que introdujo Olveira en la comunidad parroquial es un cuadernillo con documentos, imágenes, poesías y demás, destinado a un uso complementario de la catequesis.

Le dije [a otra ayudante] que quería colaborar y que yo tenía la formación de Leopoldo [Subaukar] y no la de Francisco [Olveira], y me

4 Sobre el concepto de marcación en referencia a la materialidad de las mercancías religiosas es posible consultar a Algranti (2015). 
dijo que estaría bueno que haga el curso de catequista de la diócesis de Avellaneda-Lanús, pero que dura tres años, que es una porquería y que no me servía de nada. Después hablé con Francisco y le dije que me tenía que decir qué hacer porque yo había aprendido con Leopoldo, y me dice que no me preocupe, que quería que hable más de lo social, la realidad que tenemos, que laburemos nuestros santos, que tenía un cuadernillo que me iba a dar. Es un libro que él hizo para los barrios villeros. (Entrevista a Trabajadora Social, Luján, 11 de diciembre de 2016).

Este material, que el propio sacerdote Olveira compiló hace más de veinte años, contiene, entre una profusa variedad de elementos religiosos y devocionales, referencias a varios de los mártires del canon. Allí figuran las fechas de sus asesinatos y la biografía de algunos de ellos, como por ejemplo la de Carlos Mugica:

Era de una familia famosa y rica de la Argentina: Mugica Echagüe. De joven quiere ser sacerdote. Ya siendo sacerdote descubre el dolor de la gente pobre cuando visita los conventillos de la Capital. Va con grupos de universitarios a ayudar a los trabajadores golondrinas del Chaco (cosecheros de algodón) y descubre las muchas injusticias que sufren. Comienza a trabajar en Retiro en la Villa Comunicaciones. Celebra la Misa, bautiza, casa, juega al fútbol con la gente y los defiende para que no les quiten sus tierras. Lleva a la villa a artistas, deportistas famosos, cantantes, gente de dinero, para que vean y compartan el dolor de los villeros. Hay mucha gente que se siente molesta por lo que dice y hace el P. Carlos. Lo balean el 11 de mayo de 1974 en la puerta de la Iglesia San Francisco Solano en Capital y muere poco después en el hospital Salaverry. Antes de morir deja sus últimas palabras: "Ahora más que nunca debemos estar cerca del pueblo". Lo velan en la capillita de la villa y los pobres de la villa y otros muchos, en una impresionante muestra de dolor, lo llevan en procesión hasta el cementerio de la Chacarita donde reposan sus restos. Su entrega sigue viva en el pueblo. (Documentos de campo).

Este material es tal vez el más directo en cuanto a la función pedagógica con la que son empleadas las figuras del canon. Junto con las imágenes y los otros objetos alusivos que se distribuyen por los espacios, conforman un corpus de saberes y conocimientos que 
Pedagogía de los mártires, comunidades militantes católicas y territorio: el caso de la Isla Maciel, Buenos Aires, Argentina (2016-2019).

complementan al material tradicional católico. Además de ser soportes materiales de los contenidos educacionales (principalmente religiosos en este caso), también son el contenido o la información de dicha enseñanza. Dada su ejemplaridad, la vida y obra de estos personajes son vehículos para la comprensión de valores religiosos, como así también del compromiso con las causas de los más desfavorecidos. Al preguntarle a una entrevistada sobre las imágenes de Carlos Mugica y de Enrique Angelelli relata que:

Son pilares que nosotros tenemos para, de alguna manera, enseñarle a los chicos que hay otro estilo de vida y convicciones. Son personas que murieron y no murieron de forma natural sino que fueron asesinadas por una causa justa, y a pesar de que pasen los años y ellos son nuevas generaciones, tienen que saber un poco de lo que pasó en su país. Y que estas personas para nosotros son santos porque realmente hicieron lo que el evangelio pide, ponerse en el lugar del otro y luchar por el pueblo y por la gente más humilde. (Entrevista a Ministra de la eucaristía, Convento Nuestra Señora de Fátima, Isla Maciel, Avellaneda, 14 de noviembre de 2016).

La tarea pedagógica está también fuertemente emparentada con el rescate de la memoria sobre los procesos sociales traumáticos, como lo es en este caso la experiencia represiva de la última dictadura militar. Según Ruiz-Tagle y Toledo Jofré, "la confrontación con el pasado -desde las aulas y con los estudiantes- constituye el paso previo al compromiso colectivo con una memoria cultural que desplace cualquier amenaza de repetición del pasado traumático -lastre imposible de sobrellevar" (2009, p.5). En este sentido, la complementación de la catequesis, que es principalmente una instancia de enseñanza religiosa para los niños, con la presentación de los mártires asesinados por el terrorismo de Estado está orientada a la transmisión de una memoria particular. Como todo acto de memoria implica de por sí un recorte, y es por ende, un acto presente que remite al pasado, la forma en que se realiza tiene un sentido determinado en función de las condiciones actuales. Recordar a los mártires católicos víctimas de la última dictadura militar implica, asimismo, reelaborar las consignas sostenidas por ellos y ensamblar- 
las con las demandas presentes. Además de ser una forma de cumplir con el "deber de memoria", en términos de Elizabeth Jelin (2013), para que determinada forma de violencia no se repita "nunca más", son importantes los elementos que conectan aquellas experiencias con el presente y sus contextos. En este sentido, toda figuración que acerque al imaginario del barrio (las personas de la Isla Maciel, las referencias al fútbol, las casitas coloridas, etc.) puede leerse en la clave de este ensamble.

Justamente por su relación con ese pasado traumático de la historia reciente, el pañuelo blanco de las Madres de Plaza de Mayo se presenta también aquí como un elemento con un fuerte contenido simbólico. Éste ícono, estandarte de la lucha de las madres que aún hoy continúan reclamando al Estado por el paradero de sus hijos víctimas de la represión, es un símbolo reconocido como lo es su activismo por los derechos humanos. Aparece en el convento, pintado con la técnica del stencil o graffiti y también en cartulinas producidas en instancias de aprendizaje con los niños.

Trabajamos en la catequesis con los chicos también sobre el 24 de marzo, las Madres [de Plaza de Mayo], qué había significado el pañal en la cabeza. Porque en realidad las Madres era un pañal en la cabeza lo que se ponían, que eran los pañales de tela de esa época, y que lo usaban para reconocerse entre ellas y porque era algo que representaba a sus hijos, y después se transformó en pañuelo, y cómo relacionamos el Evangelio y la catequesis con la práctica concreta. (Entrevista a Catequista, bar La Dignidad, Villa Crespo, ciudad de Buenos Aires, 5 de abril de 2017).

De esta forma, se completa un argumento pedagógico que parte de la vinculación de los valores religiosos con el compromiso social, continúa con la ejemplaridad de las figuras que encarnaron esas posturas y sus martirios, y, finaliza con el reconocimiento y la solidaridad para con otras víctimas, como las Madres de Plaza de Mayo. 
Pedagogía de los mártires, comunidades militantes católicas y territorio: el caso de la Isla Maciel, Buenos Aires, Argentina (2016-2019).

\section{LA CAPILLA BEATO ÓSCAR ROMERO}

Visitando un espacio más de la constelación parroquial de la Isla Maciel es posible trabajar en relación al concepto del sufrimiento. La "otra" capilla, bautizada recientemente Beato Óscar Romero, está ubicada en un sector del barrio mucho más precario llamado La Pinzon. Anteriormente funcionaba a su lado la capilla Nuestra Señora de Itatí, pero ese espacio ahora es utilizado como una sala de reuniones o para el comedor infantil. La construcción de la capilla Beato Óscar Romero fue proyectada durante años por el equipo parroquial y el de la Fundación Isla Maciel y se inauguró en mayo del 2017 en un evento que se describirá más adelante. El lugar es modesto, de hecho la nave es muchísimo más pequeña que la de la otra parroquia, sin embargo es nuevo y tiene numerosos murales y cuadros que le otorgan gran vitalidad. En el atrio, y a través del ábside vidriado, se ven murales coloridos con imágenes del beato Romero siendo perseguido, resistiendo y finalmente asesinado por las fuerzas militares. Estas imágenes del sufrimiento están acompañadas con sus frases más memorables como la que reza: "si me matan, resucitaré en el pueblo". En la nave hay varios cuadros, estatuas de la Vírgen María, retratos del papa Francisco, crucifijos y demás símbolos religiosos. Una pintura llama poderosamente la atención. 


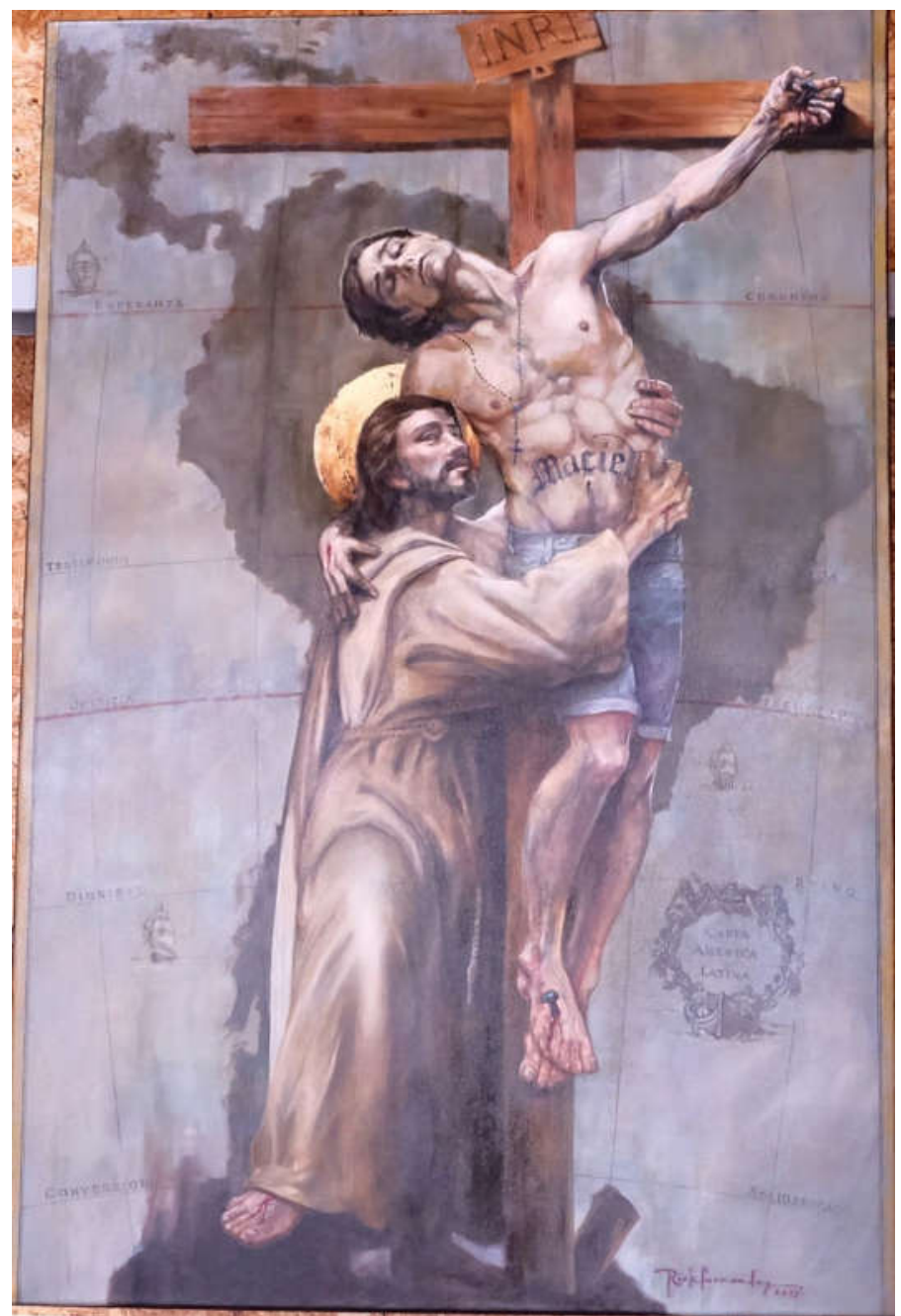

3. Pintura de Ricardo Fernández en el interior de la capilla Beato Óscar Romero, Isla Maciel, Avellaneda. Fotografía propia, 17 de mayo de 2017.

En la misma aparece crucificado y desvanecido un joven con el torso descubierto, bermudas de jean y un tatuaje que dice "Maciel". Junto a él, la imagen que representa a Jesucristo, con mirada serena, lo sostiene y parece estar "bajándolo de la cruz". Ambos 
Pedagogía de los mártires, comunidades militantes católicas y territorio: el caso de la Isla Maciel, Buenos Aires, Argentina (2016-2019).

tienen las manos y los pies ensangrentados, aunque Jesucristo ya no está clavado al crucifijo. El fondo es un mapa de Sudamérica en el que se leen las palabras vida, esperanza, testimonio, comunión, liberación, reino, solidaridad, dignidad y conversión. Cuando en la parroquia Nuestra Señora de Fátima se leía "bajemos a los pobres de la cruz" acá se ve una imagen concreta de esa acción.

Para mí ese cuadro significa eso. Mostrar la iglesia que es una iglesia pobre, de los pobres y para los pobres. Para mí es una iglesia real, concreta, totalmente nueva, en el sentido de la inclusión y de acercarse a la vida, a la vida de la persona que realmente sufre y que siempre se la relegó, se la negó porque era un mandato divino. (Entrevista a Trabajadora Social, Luján, 11 de diciembre de 2016).

La interpretación que hace la entrevistada del cuadro permite entender la forma en que ese objeto condensa la línea liberacionista antes mencionada. El muchacho representa a toda la población de la Isla Maciel (como lo indica su tatuaje), en la actualidad (como se infiere por la ropa de moda), y, por extrapolación, a Latinoamérica (como indica el mapa del fondo). La referencia continental no es vana ya que, al igual que otras alusiones, como las banderas de los países desplegadas en la parroquia, puede entenderse como una apelación al catolicismo latinoamericano que, además de una impronta identitaria, connota la construcción de legitimidades alternativas con miras a eludir tensiones con las autoridades del episcopado nacional. ${ }^{5}$ La interpretación del sufrimiento está orientada hacia ese sujeto sufriente que representa a la comunidad (los pobres), y que podrían ser también "los pobres" como sujetos sociales de la llamada "Opción por los Pobres". Otra formulación del sufrimiento va a estar mucho más relacionada con la rememoración del pasado trágico y con la pérdida de las víctimas, como pueden ser los sacerdotes asesinados o el conjunto de perseguidos, asesinados y/o desaparecidos durante la última dictadura. Ambas aristas se conjugarán en las tareas pedagógicas.

En este punto es posible establecer el diálogo con el trabajo

5 Un análisis histórico sobre los procesos institucionales en el catolicismo latinoamericano y, en particular, en relación al Consejo Episcopal Latinoamericano y su rol en las disputas de autoridad continental es posible hallarlo en Bonnin (2013). 
de Dolores San Julián (2017) en el que se analizan los actos en homenaje a las víctimas de la última dictadura militar en el país. En ese escrito se reflexiona sobre las conmemoraciones que se realizan en la Iglesia de la Santa Cruz del grupo de víctimas conocido como "los 12 de la Santa Cruz". En esos homenajes, los familiares de las víctimas, junto a las Madres de Plaza de Mayo le colocan simbólicamente el pañuelo blanco a la estatua de la Virgen María. En esas conmemoraciones "lo que se resalta no es tanto el sufrimiento sino el 'apasionamiento', de las Madres y de María, entendido como aquello que motoriza la acción política y religiosa" (San Julián, 2017). De un modo similar, los cuadros e imágenes en la parroquia permiten establecer un puente de empatía y aprendizaje asimilando los sufrimientos de los "pobres" con los de aquellos que han sido víctimas o sus familiares. A partir de este punto se hace posible la construcción de un activismo socio religioso que rescata y pone en práctica las consignas de los mártires.

\begin{abstract}
Alguna gente de acá del barrio ya conocía a Mugica, de hecho hay fotos de gente del barrio con Mugica, por ahí la gente más vieja del barrio. Otras de a poco con él, en el caminar de Francisco [Olveira] van conociendo, profundizando más el tema, porque el otro cura que teníamos no era de esta ideología, imaginate que no había nada, solamente estampitas de santos y cosas, no había ninguna bandera de Bolivia ni Paraguay todas mezcladas. Si entrás en la parroquia tenemos todas las banderas de todos los países Latinoamericanos y los chicos que hacen cosas que trabajan en la catequesis están pegadas en la pared, sea pañuelitos de Plaza de Mayo como la foto de la Virgen María, o sea, se trabaja todo y los chicos los ponen en la misa como regalo y se va pegando en las paredes. Quizá en otras parroquias no ves eso, porque por ahí está mal visto o la gente no lo entiende. (Entrevista a Ministra de la eucaristía, Convento Nuestra Señora de Fátima, Isla Maciel, Avellaneda, 14 de noviembre de 2016).
\end{abstract}

Esta referencia condensa de un modo contundente la forma en se construye pedagógicamente un tipo de memoria y una identidad tanto religiosa como comunitaria, y en la cual las figuras del canon cumplen un rol destacado. También refleja la importancia de la re- 
Pedagogía de los mártires, comunidades militantes católicas y territorio: el caso de la Isla Maciel, Buenos Aires, Argentina (2016-2019).

conversión a esta "otra" forma de iglesia y la legitimidad que aporta el sufrimiento, tanto de aquellos personajes que lucharon antes como el de los pobres actuales. Por otro lado, la repetición de las imágenes es también un recurso pedagógico eficaz, "la reiteración constituyó durante largo tiempo el modo privilegiado de transmisión, controlado por los educadores, de textos considerados, si no como fundadores de la cultura enseñada, al menos como prestigiosos, en el sentido de textos que sientan cátedra, crean autoridad" (Ricoeur, 2000, p.85). Por último, es posible ubicar los usos de las imágenes, siguiendo a Gruzinski (1994), en un marco más amplio en relación a la historia de evangelización cristiana en el continente americano. Si, por un lado, la figuración, por su facilidad de comprensión, ha sido elemento de comunicación y de inculcación cultural para las poblaciones indígenas; por otro, han sucedido procesos de apropiación y de readaptación de las imágenes con nuevos sentidos, tanto de resistencia como identitarios. Esta ambivalencia también puede percibirse como una tensión presente en las obras de la comunidad parroquial de la Isla Maciel.

\section{ACTOS Y CONMEMORACIONES: LAS IMÁGENES EN MO- VIMIENTO Y EL ARMADO DE REDES DE ACTIVISMO POR LOS DERECHOS HUMANOS}

Además de las mencionadas imágenes de los mártires del $c a$ non o las alusiones a la lucha por los derechos humanos, también se observan referencias a las afinidades de la política actual, en particular a las expresiones del arco peronista y, más concretamente, del kirchnerismo. Esta vinculación con las causas sociales, humanitarias y políticas que excede los soportes materiales, debe observarse en sus expresiones performáticas. ${ }^{6}$ Los miembros del grupo de Curas en Opción Por los Pobres han forjado relaciones con diversos protagonistas del entramado activista por los derechos humanos que reclama justicia por los crímenes del terrorismo de Estado y con activistas políticos del kirchnerismo. Particularmente, con la asociación

6 Se usará el concepto de performance en tanto puesta en escena, teatralidad, actividades conmemorativas que suceden en un escenario, con un guión y que requieren la presencia de las personas, tal como es presentado en los trabajos de San Julián (2017) y Taylor (2000). 
Madres de Plaza de Mayo y su titular, Hebe de Bonafini, y con el intendente del partido de Avellaneda (al que pertenece la Isla Maciel), Jorge Ferraresi.

La intención es, entonces, observar y analizar la vinculación entre la simbología que se le atribuye a los mártires del canon en una serie de actos y conmemoraciones, es decir, ya no solo en su presentación material, sino en la acción, en el movimiento, y en la interacción con actores de otros espacios. Será interesante destacar lo performático de algunos de estos actos y visualizar el modo en que se van tejiendo redes de alianzas y afinidades con actores externos a la propia comunidad barrial.

\section{LA FIGURA DEL SACERDOTE PABLO GAZZARRI}

El canon de los mártires materializado en la construcción de la constelación de espacios de la parroquia deja entrever un trabajo de selección entre el clero víctima del terrorismo de Estado. En ese marco, surgió como interrogante la ausencia de la figura de Pablo Gazzarri. Este sacerdote era parte del clero y pertenecía a la congregación Fraternidad del Evangelio en el momento de su desaparición forzada, el 27 de noviembre de 1976. Catoggio describe su caso como emblemático del mecanismo de borramiento de la condición religiosa y adjudicación de la condición subversiva por parte de las fuerzas represivas a determinados actores del clero, lo que les supuso la pérdida de "privilegios" al momento de su persecución (2016a: 133-135). Sin más posibilidad que la de conjeturar sobre lo que no está, se pueden arriesgar algunas líneas de pensamiento sobre esta omisión. Habiendo Gazzarri desarrollado buena parte de su acción pastoral en la Isla Maciel, parecería lógico que, dada su condición de desaparecido, hubieran sendos homenajes y menciones en su memoria. Incluso la labor pedagógica podría resultar mucho más idónea dada la cercanía de esta figura con el espacio social, y por ende, la simplificación para cualquier trabajo de asociación. En el tiempo que duró la labor de campo éstas referencias no se observaron, con lo cual, o no estuvieron presentes o lo estuvieron pero con mucha menor visibilidad. 
Adicionalmente, un hecho significativo tuvo lugar a raíz de un evento en su memoria realizado en el Sitio de Memoria ESMA el 25 de noviembre de 2017 en el cual fue invitado el sacerdote Olveira. $\mathrm{Al}$ recibir la participación a tal evento y en comunicación con una de las catequistas del grupo se constató que ella desconocía totalmente la figura de Pablo Gazzarri. Esta informante, una mujer católica que nació y vivió en la Isla Maciel, es alguien que se ha sumado al equipo del padre Olveira desde su llegada, doce años atrás. Este desconocimiento de la figura de Gazzarri por parte de una activista católica comprometida en el mismo territorio en el que él hubo de transitar provocó un gran desconcierto. ¿No debería ser Gazzarri una figura ejemplar para las personas de la Isla Maciel? ¿No debería estar mucho más presente que Angelelli o Romero dada su cercanía?

Más allá de lo que grafica la anécdota, un primer punto a tomar en consideración tiene que ver con los diferentes niveles de importancia que van adquiriendo algunos personajes. Sin duda rememorado y homenajeado, a nivel general Gazzarri no cuenta con la reverberancia o la fama de las otras figuras, con lo cual podría llegar a resultar trabajosa su inclusión como figura pedagógica. Sin embargo, un segundo punto resulta más interesante. A diferencia de otros casos en que los imaginarios han elaborado aquella condición de "víctimas inocentes", para el caso de Gazzarri esto sería mucho más difícil de sostener. Su compromiso militante lo llevó a participar de agrupaciones del arco peronista que sostuvieron la lucha armada. Tanto es así que del religioso se recuerda su identificación y filiación con la agrupación armada Montoneros en igual medida que su condición de sacerdote católico (Catoggio, 2016b). Más allá de los copiosos debates sobre la aceptación o el rechazo a la utilización de las armas como medios para el cambio social, prevalece un dejo generalizado de censura y deslegitimación frente a tales posturas. Por lo tanto, y en el caso analizado, lo que se podría calificar como expresión de una amnesia selectiva funciona como una suerte de velo de auto protección y una adecuación al público interlocutor. Si bien el padre

7 Resulta pertinente una mención sobre el mecanismo que distingue a las víctimas entre "inocentes" y "culpables". Sin intención de mantener la vigencia de esta forma acusatoria, que en el fondo podría vincularse con la llamada "teoría de los dos demonios", la idea es interpretar los sentidos que los actores les adjudican a los elementos con que interactúan. 
Olveira se permite participar en la rememoración de esta figura, ello tal vez sea a condición de hacerlo en determinados círculos -como los del activismo por los derechos humanos- en donde la reflexión ha transitado etapas en las que la mención a las militancias ha dejado de ser eludida para ser reconsiderada y ponderada. ${ }^{8}$ Sin embargo, en ambientes con menor carga simbólica que la que condensa el sitio de memoria de la Ex-ESMA, o frente a audiencias más amplias o menos preparadas, el recurso a los mártires se ciñe de un modo más estricto al canon, lavando aquellos contenidos que podrían resultar polémicos. No se trataría entonces de un ocultamiento sino más bien de una adecuación frente a interlocutores que son percibidos con diferentes capitales culturales o intelectuales para asimilar o no determinados relatos. Además, el juego de las legitimidades hace que sea mucho más fácil defender aquellas figuras ya consagradas o que cuentan con el hálito de la "inocencia". Sobre todo si se tiene en cuenta la tensa relación que existe con la jerarquía institucional católica, de orientación conservadora, sobre la cual se reflexionará más adelante. Con todo, la ausencia de Gazzarri puede ser leída en los términos de una amnesia que manifiesta la incapacidad de incorporarlo narrativamente (al menos en determinados espacios):

Los acontecimientos traumáticos conllevan grietas en la capacidad narrativa, huecos en la memoria. Como veremos, es la imposibilidad de dar sentido al acontecimiento pasado, la imposibilidad de incorporarlo narrativamente, coexistiendo con su presencia persistente y su manifestación en síntomas, lo que indica la presencia de lo traumático. En este nivel, el olvido no es ausencia o vacío. Es la presencia de esa ausencia, la representación de algo que estaba y ya no está, borrada, silenciada o negada. (Jelin, 2002, p.28) 


\section{EL GRUPO DE CURAS EN OPCIÓN POR LOS POBRES Y LAS MADRES DE PLAZA DE MAYO}

La participación de Olveira en eventos y actos por fuera del territorio permite la construcción y la consolidación de una serie de alianzas estratégicas. La más cercana o íntima está referida al propio ámbito religioso y en particular, al grupo de Curas en Opción Por los Pobres, sobre el cual Olveira relata:

Vendría a ser como un movimiento pero no formal porque no tene- mos ninguna personería jurídica ni religiosa, [...] somos un grupo de curas de todo el país que nos une una misma visión de iglesia que es desde la opción de los pobres, o si vos querés, desde la teo- logía de la liberación. [...] Nos reunimos cada dos meses y tenemos un encuentro anual de una semana, hacemos comunicados públi- cos muchas veces por distintas temáticas, como por el [repudio al] " $2 \mathrm{x} 1$ "” $\mathrm{o}$ por cosas que tienen que ver con la realidad que estamos viviendo y ahí yo participo formalmente, acompañamos el tema de la libertad de Milagro Sala. [...] Somos bastante inorgánicos, muy poco organizados. Hay un secretariado formado por Eduardo de la Serna, Marcelo Ciaramella y Roberto Murall [...] ellos tienen nues- tro aval para hacer algún comunicado público. (Entrevista a Fran- cisco Olveira, El revolucionario bar, cuidad de Buenos Aires, 29 de mayo de 2017). ${ }^{10}$

Además de las publicaciones del grupo, que suelen tener cier- ta repercusión en los medios de comunicación, sus miembros par- ticipan en diversos eventos públicos donde concurren agrupados o en solitario, pero comúnmente en representación del conjunto. El activismo así desarrollado tiende a ensamblar manifestaciones de carácter político con elementos de la liturgia católica. En más de una ocasión, las agrupaciones sociales convocan a miembros del grupo a movilizaciones en las que, durante del desarrollo de los actos po- líticos convenidos, se dispone de un segmento protagonizado por el grupo. De esta forma, no resulta inusitado asistir a la realización de misas $a d$ hoc en las que la oración religiosa se eleva in situ, es decir,

9 En el 2017 la Corte Suprema de Justicia extendió a los condenados por delitos de lesa humanidad durante la última dictadura militar el llamado beneficio del " $2 \mathrm{x} 1$ " que les reduciría las condenas, aunque eso fue posteriormente revertido. El grupo de Curas en Opción Por los Pobres respondió públicamente al obispo castrense y a un editorial del diario La Nación que defendían dicho beneficio. 10 El Revolucionario Bar, situado frente a la Plaza de Mayo, también se conoce coloquialmente como "el bar de las Madres" porque allí funciona la Asociación Madres de Plaza de Mayo. Consecuentemente, es un espacio de actividad política. En la ocasión de la entrevista con Olveira, fue él quien sugirió realizarla en ese lugar porque tenía previsto un encuentro con Hebe de Bonafíni. En el mismo, ella le entregó una donación para el comedor infantil de la Isla Maciel consistente en un costal de vegetales que "Paco" retiró cargándolo en su motocicleta. 
en el ámbito público y por fuera de los templos religiosos, con la finalidad de bendecir, performáticamente, los cometidos de la protesta. A pesar de que los miembros del grupo perciben cierta falta de organicidad en su agrupación, a lo largo de estas presentaciones conforman una camaradería que los afianza como equipo. Del mismo modo, van entretejiendo redes de solidaridad con actores sociales y activistas de otros campos.

Es destacable, en particular, su relación con la agrupación Madres de Plaza de Mayo, con la cual han colaborado reiteradamente, llegando incluso a participar en sus emblemáticas "rondas de los jueves"11 en la Plaza de Mayo. Coronando estas experiencias de cooperación, el 15 de octubre del 2017 se realizó un evento alusivo a esta relación fraternal en la parroquia Nuestra Señora de Carupá, Tigre. Con motivo del "día de la madre", las Madres de Plaza de Mayo les entregaron simbólicamente su pañuelo blanco a los Curas en Opción por los Pobres (Homenaje..., 2017; Entregaron..., 2017).

ML La "ronda de las madres" o "marcha de las madres" es una actividad de protesta pacífica que realizan las Madres de Plaza de Mayo todos los días jueves desde el año 1977, es decir, desde hace 41 años. La finalidad de la misma es la de exigir al gobierno información y justicia sobre el paradero de sus hijos que han sido secuestrados y desaparecidos por las fuerzas represivas. 
Pedagogía de los mártires, comunidades militantes católicas y territorio: el caso de la Isla Maciel, Buenos Aires, Argentina (2016-2019).

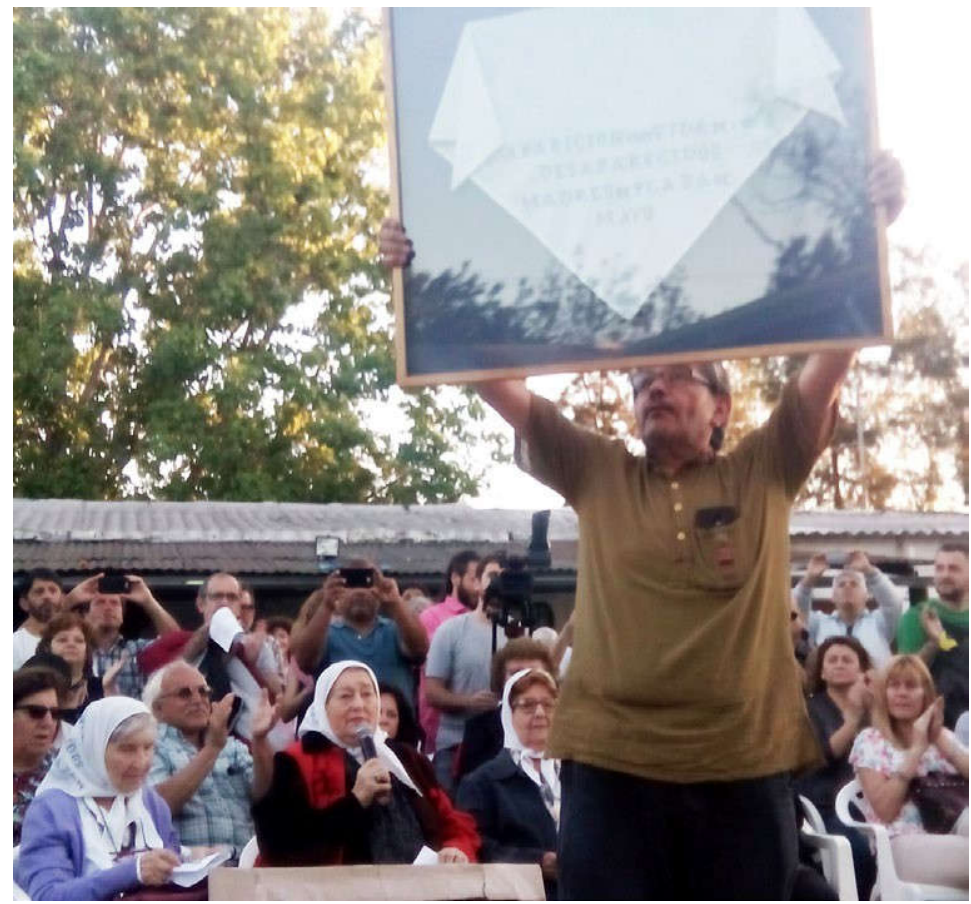

4. Las Madres de Plaza de Mayo entregan el pañuelo blanco al grupo de Curas en Opción Por los Pobres, parroquia Nuestra Señora de Carupá, Tigre. Fotografía propia, 15 de octubre de 2017.

Entre los presentes, además del sacerdote Olveira, estuvieron varios miembros del grupo de Curas en Opción Por los Pobres, incluido el sacerdote Eduardo de la Serna, uno de sus referentes más destacados y quien mantiene una afectuosa relación con Hebe de Bonafini. La elección del lugar no fue azarosa, se trata del sitio en el que en 1976 fue asesinado el sacerdote Francisco "Pancho" Soares por parte de la dictadura. En los discursos proferidos durante esa tarde no faltaron las metáforas eclesiológicas. Así, por ejemplo, el suelo del patio de la parroquia era un lugar "santo" que había sido "regado" con la sangre del "mártir". Si bien Soares no integra el canon con el que se trabaja en la parroquia de la Isla Maciel puertas adentro, en determinadas circunstancias dicho canon puede ser estratégicamente extendido. 
Las figuras de las víctimas, se trate de Soares o de otros miembros del clero que han sido perseguidos, permiten una conectar por empatía con las Madres de Plaza de Mayo. Se trata de un sufrimiento que es compartido, en este caso entre quienes han perdido a sus familiares y quienes perdieron a los que hoy son sus referentes. Retomando a Dolores San Julián (2017), existe cierta asimetría en los rituales conmemorativos. En ambos está presente la figura de las Madres de Plaza de Mayo, ya sea en persona o a través del símbolo que distingue su lucha: el pañuelo blanco. Sin embargo, en esta ocasión los miembros del grupo de Curas en Opción Por los Pobres son reconocidos por las Madres con la entrega simbólica de su pañuelo. Es decir, el grupo religioso es agraciado por activistas y referentes de la sociedad civil, mientras que en la Santa Cruz es el pañuelo blanco el que ingresa al ámbito de lo sagrado al ser colocado en la estatua de la Virgen María.

Estas relaciones también tienen lugar en el propio territorio. En noviembre del 2016 se realizó la inauguración de una pintura mural ${ }^{12}$ en el muro externo del convento de la Isla Maciel. En el mismo se retrata el rostro de la propia Hebe de Bonafini, rodeado de pañuelos blancos con los nombres de los desaparecidos por la última dictadura oriundos o habitantes de la Isla Maciel (significativamente, el nombre del sacerdote Pablo Gazzarri no figura en la obra, a pesar de haber realizado parte de su labor pastoral allí). Al evento concurrieron Hebe de Bonafini, otras Madres de Plaza de Mayo y el intendente de la localidad, Jorge Ferraresi, quienes dieron sus discursos junto al sacerdote Olveira. El acercamiento al territorio de actores con los que se van tejiendo alianzas, además de confirmar el apoyo mutuo, supone la transferencia mutua del reconocimiento que viene aparejado a su fama o prestigio. El renombre de las Madres y la centralidad del intendente local permiten que Olveira y su comunidad parroquial sean ensalzados, por propiedad transitiva, cuando reciben sus visitas.

12 EI difundido uso de esta técnica tiene un correlato local dada la existencia de algunos proyectos muralistas en la Isla Maciel, siendo el grupo "Pintó la Isla" uno de los más destacados. Esta agrupación ha participado conjuntamente con los miembros de la comunidad parroquial. Se puede consultar una reciente nota periodística en Esses (2018). 
Pedagogía de los mártires, comunidades militantes católicas y territorio: el caso de la Isla Maciel, Buenos Aires, Argentina (2016-2019).

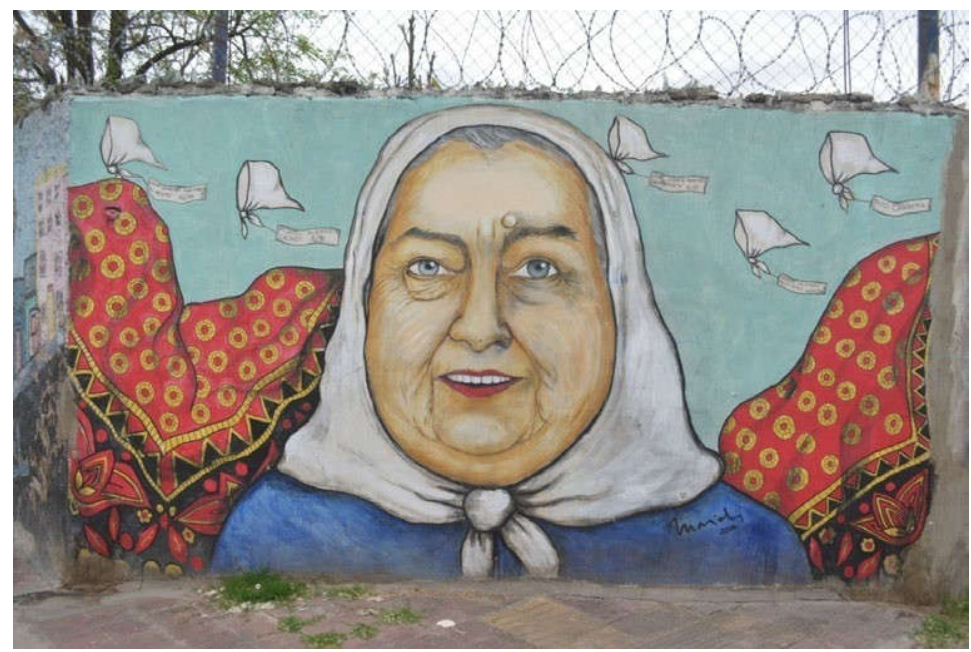

5. Mural de la artista Mariali con la imagen de Hebe de Bonafini en el Convento Nuestra Señora de Fátima, Isla Maciel, Avellaneda. Fotografía propia, 1 de diciem- bre de 2018.

\section{LA INAUGURACIÓN DE LA CAPILLA BEATO ÓSCAR ROMERO}

Tiempo después, se realizó un evento en el que se evidenciaron las distintas alianzas con actores sociales y el trasfondo significativo de las figuras de los mártires. El 27 de mayo del $2017 \mathrm{se}$ inauguró en la Isla Maciel la capilla Beato Óscar Romero, emplazada junto al lugar donde hasta entonces funcionaba la capilla Nuestra Señora de Itatí (devenida en sala de reuniones). El sacerdote Olveira gestionó su construcción en colaboración con la comunidad y la Fundación Isla Maciel. El evento tuvo una notable envergadura gracias a una concurrida asistencia de fieles y público en general, y gracias a la venerabilidad de los invitados. Además de la presencia obligada del obispo de dicha diócesis -la de Avellaneda/Lanús- Rubén Frassia, también estuvieron Jorge Ferraresi, el intendente de San Antonio de Areco, Francisco Durañona y el embajador de El Salvador, Oscar Menjíbar Chávez, quien conoció a Óscar Romero en persona y dedicó unas palabras llenas de emotividad. 
Durante la misa participaron varios miembros del grupo de Curas en Opción Por los Pobres exhibiendo la forma en que trabajan y afianzan sus vínculos. Asimismo, la colaboración con miembros de la política local, ligada al kirchnerismo, como el intendente Ferraresi, evidenció el compromiso del sacerdote con esa línea política. El acercamiento al peronismo no es nuevo en la historia del grupo de Curas en Opción Por los Pobres ni en la de la parroquia de la Isla Maciel. En primer lugar, la parroquia suele colaborar con la agrupación kirchnerista La Cámpora, a veces en su propio espacio. Asimismo, en un hecho que ha sido difundido por los medios de comunicación, tras la realización de una misa en homenaje al padre Mugica, el grupo de curas entonó festivamente la Marcha Peronista (Después..., 2017). Finalmente, en el 2016 la ex presidenta Cristina Fernández de Kirchner visitó la Isla Maciel para reunirse con el grupo de Curas en Opción Por los Pobres (Cristina..., 2016). Estos sucesos han sido criticados por quienes no avalan la intervención en espacios político partidarios por parte de miembros de la iglesia. La réplica a esas críticas apela al mandato evangélico de compromiso con los pobres y/o con quienes (políticos incluidos) mejor representen sus intereses (en este caso, el kirchnerismo). La identificación con el peronismo es usual entre los Curas en Opción Por los Pobres que ven en dicho movimiento una forma de ayudar a los pobres, e incluso toman la conocida afinidad de muchos sacerdotes del MSTM con el peronismo como una legitimación. Los libros de Rolando Concatti (1972) y Carlos Mugica (1973) manifiestan claramente esta "opción por el peronismo". Del mismo modo, las referencias a los mártires del $c a$ non son frecuentes y forman parte de su identidad grupal. Ejemplo de ello son sus estolas que llevan estampadas las imágenes y frases de varios de ellos (Angellelli, Mugica, Romero, Duquet y Domon).

Volviendo a la inauguración de la capilla, es interesante ob-

servar la forma en que se relacionan con actores que representan a otros espacios del catolicismo. Por su condición de obispo, Rubén Frassia encarna un rol jerárquico con respecto a Olveira, con quien a su vez mantiene la tensión propia de cierta distancia ideológica, administrada diplomáticamente por ambos, siempre y cuando no se superen ciertos límites tácitamente establecidos. Según Olveira: 
Pedagogía de los mártires, comunidades militantes católicas y territorio: el caso de la Isla Maciel, Buenos Aires, Argentina (2016-2019).

Él [el obispo Rubén Frassia] me deja hacer, trabajar, se banca muchas cosas, la inauguración de ayer [de la capilla Beato Óscar Romero] él se la tiene que bancar [...] que lleva el nombre del beato Óscar Romero, que decimos que es la capilla de nuestros mártires latinoamericanos donde nombramos varias veces a Milagro Sala, donde el Intendente [Jorge Ferraresi] le bajó línea [al obispo] sobre el tema de la reconciliación [...] los dos sabemos que ideológicamente no comulgamos pero me deja trabajar. Un cura en un barrio intenta acompañar la vida del barrio y el sufrimiento del barrio, no es una cuestión estrictamente religiosa, yo no separo que esto sea religioso y que esto no sea religioso, para mí es tan religioso hacer un bautismo como cortar una ruta, todo tiene que ver con lo mismo, desde mi caso, de la fe en dios, un dios liberador que quiero que oriente mis acciones, pero que tanto una como la otra son exactamente igual de religiosas. (Entrevista a Francisco Olveira, El revolucionario bar, cuidad de Buenos Aires, 29 de mayo de 2017).

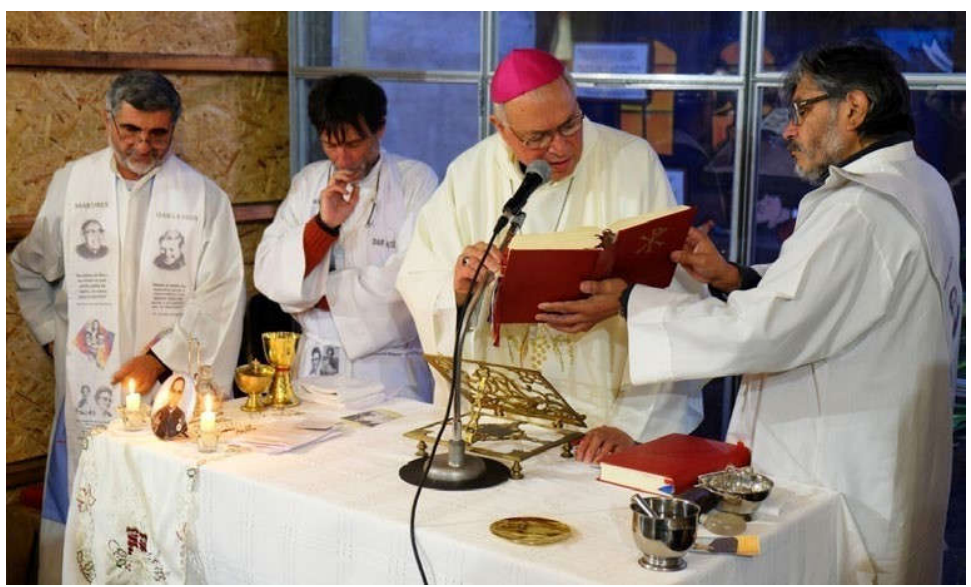

6. El obispo preside la misa junto a los Curas en Opción Por los Pobres en la inauguración de la capilla Beato Óscar Romero, Isla Maciel, Avellaneda. De izquierda a derecha: Alberto Nucci, Francisco Olveira, Rubén Frassia y Ricardo Carrizo. Fotografía propia, 27 de mayo de 2017. 


\section{TENSIÓN Y RUPTURA}

La inestabilidad del equilibrio se manifiesta en desencuen- tros que, por lo general, suelen ser tolerados en tanto las prácticas heterodoxas no adquieran trascendencia pública: una actitud que pudiera resultar osada o provocativa lo es mucho más si obtiene co- bertura mediática. Además del apoyo al peronismo o a las causas políticas como la de la liberación de Milagro Sala hay otros temas que foguean los desacuerdos. Durante el 2018, los debates públicos en torno al proyecto de ley para la despenalización de la interrupción voluntaria del embarazo generaron que muchas figuras tomaran una $\mathrm{u}$ otra postura de manera pública. Si bien Olveira nunca afirmó estar a favor de la despenalización, emitió opiniones que no fueron tajan- temente en su contra. En particular, consideró que como sacerdote no le negaría el perdón a una mujer que hubiera abortado y también afirmó que la problemática debería ser tratada como un problema de salud pública (una de las principales reivindicaciones que esgrimen quienes promueven la aplicación de la ley). El periódico Infobae pu- blicó el 27 de julio una nota bajo el título "Francisco 'Paco' Olveira, el cura que está a favor de la despenalización del aborto y el preser- vativo" generando gran revuelo, a pesar de que el cuerpo de la nota no cumple la promesa del título (Francisco..., 2018). Tal vez teniendo en cuenta antecedentes como el caso del sacerdote Nicolás Alessio, que en el 2013 fue sancionado por opinar a favor del matrimonio entre personas del mismo sexo (El Vaticano..., 2013), Olveira evita transgredir ciertos límites. Él mismo ha expresado: "si digo abierta- mente mi postura frente al aborto me podrían excomulgar" (Es una cuestión..., 2018).

Meses después, ateniéndose a lo estricto de la normativa ca-

tólica, Frassia decidió que Olveira trabajaría en la Isla Maciel hasta diciembre de ese año y que, pasado ese tiempo, debería regresar a la diócesis a la cual pertenece, la de Merlo-Moreno. Esto ha sido interpretado como una ruptura, e incluso, como una actitud auto- ritaria por parte del obispo. Esto desencadenó los sucesos que nar- rados al inicio de este artículo. El nuevo párroco designado, Mario Ghisaura modificó algunas significativas disposiciones espaciales: retiró cuadros de las figuras del canon, borró murales realizados por la comunidad, rehusó usar el nombre "Beato Óscar Romero" para la capilla recientemente bautizada y modificó la orientación de la misa en la capilla Nuestra Señora de Fátima, de modo tal que, al rezar, los 
Pedagogía de los mártires, comunidades militantes católicas y territorio: el caso de la Isla Maciel, Buenos Aires, Argentina (2016-2019).

feligreses ya no estén de frente al mural del ábside sino a una pared lateral. Interpretadas estas modificaciones, justificadamente, como provocaciones por parte de la comunidad parroquial que se nutrió durante la gestión de Olveira, se desencadenó un despliegue de denuncias en cartas abiertas y una pulseada en torno a los apoyos y a las adhesiones. Las reflexiones más amargas entre los colaboradores de la parroquia asocian estas actitudes con el contexto socio político vivido bajo el gobierno de Mauricio Macri y entienden el borramiento de las figuras de la memoria como una actitud negacionista. En su primera carta hay una expresión que resuena de un modo muy particular: denuncian que el nuevo sacerdote "bajó los cuadros" de los mártires, pero que ellos recuerdan "el tiempo en que en nuestra Patria se bajaban los cuadros de los genocidas que asesinaron a nuestros mártires" (Uranga, 2019) en referencia al momento en que en el 2004, por orden del entonces presidente de la nación, Néstor Kirchner, se bajaron los cuadros de los genocidas en el Colegio Militar de El Palomar. La alegoría cobra fuerza si se tiene en cuenta que la escena que Néstor Kirchner protagonizó simboliza la inauguración de una etapa histórica de políticas de memoria impulsadas desde el Estado mientras que su imagen especular, la bajada de cuadros de Ghisaura, tiene lugar en una época signada por la desconfianza y el desmantelamiento estatal de buena parte de esas políticas.

\section{CONCLUSIONES}

Como se desprende de esta recorrida, la pedagogía de los mártires ha permitido construir una comunidad militante en la isla Maciel excediendo lo meramente devocional y litúrgico y funcionando como plataforma para la articulación de distintos activismos de las víctimas enlazando pasado y presente. Puertas adentro, la comunidad se valió del ejemplo de los mártires que han sido "perseguidos justamente" y sufrieron por defender una determinada forma de catolicismo muy vinculada a esa cuestión social. Pedagógicamente, se han utilizado para la construcción de una identidad ligada a las problemáticas concretas barriales y a la memoria como un acto presente. Puertas afuera, estas figuras han sido insignia de un colec- 
tivo más amplio articulado por el grupo de Curas en Opción Para los Pobres que, mediante sendos homenajes y actividades performáticas, ha forjado alianzas en el terreno social, humanitario y político, agudizando, al mismo tiempo, las tensiones con los sectores conservadores del catolicismo. Estas tensiones no se expresaron solo en el seno de la institución eclesiástica, sino que han reflejado cambios en las relaciones de fuerza del mundo católico que está ligado a los vaivenes de la política del país. En este contexto se ubica la reciente decisión del obispo Frassia de nombrar a un nuevo párroco en la Isla Maciel, mucho más compatible con su propia orientación ideológica. El significado simbólico que ha tenido para la comunidad parroquial este cambio de autoridad religiosa, y las modificaciones realizadas sobre el espacio y las prácticas litúrgicas, puede comprenderse mejor luego de haber demostrado la centralidad que tuvieron estos elementos para la construcción de la identidad colectiva en esa comunidad.

\section{REFERENCIAS}

ALFARO SIQUEIROS, D. et al. Manifiesto del Sindicato de Obreros Técnicos, Pintores y Escultores. Sala de Arte Público Siqueiros, Ciudad de México, 1923.

ALGRANTI, J. La materialidad de las creencias. Análisis de las formas rituales de consumo religioso. 2015. Ponencia. XI Jornadas de Sociología. Facultad de Ciencias Sociales, Universidad de Buenos Aires, Buenos Aires.

ARIAS, J. A. El Grupo de Curas en Opción Preferencial por los Pobres: Los herederos del Movimiento de Sacerdotes para el Tercer Mundo. 2016. Tesis (Licenciatura). Universidad Nacional de La Plata. Facultad de Humanidades y Ciencias de la Educación.

BARRAL, M. E. Curas con los pies en la tierra. Una historia de la Iglesia en la Argentina contada desde abajo. Buenos Aires: Sudamericana, 2016.

BONNIN, J. E. Discurso politico y discurso religioso en América Latina. Leyendo los borradores de Medellín (1968). Buenos Aires: Santiago Arcos Editor, 2013.

CATOGGIO, M. S. Católicos en el "mundo de los pobres". Imaginarios y sentidos frente a la situación represiva durante la última dictadura 
Pedagogía de los mártires, comunidades militantes católicas y territorio: el caso de la Isla Maciel, Buenos Aires, Argentina (2016-2019).

militar argentina, 1976-1983. En: MALLIMACI, F. y JUDD, E. (coord.) Cristianismos en América Latina. Tiempo presente, historias y memorias. Buenos Aires: CLACSO, 2013.

CATOGGIO, M. S. Los desaparecidos de la iglesia: el clero contestatario frente a la dictadura. Buenos Aires: Siglo Veintiuno Editores, $2016 \mathrm{a}$.

CATOGGIO, M. S. Mecanismos desacralizadores de la represión ilegal: las figuras del "culpable" y "el arrepentido". 2016b. Ponencia. Segundas Jornadas de Trabajo de la Red de Estudios sobre Represión y Violencia Política, IDAES, Buenos Aires.

CONCATTI, R. Nuestra opción por el peronismo. Buenos Aires: Publicaciones del Movimiento de Sacerdotes para el Tercer Mundo de Mendoza, 1972.

CRISTINA Kirchner visita una parroquia en la Isla Maciel. Clarín, Buenos Aires, 19 de abril de 2016. Política. Recuperado de: https://www.clarin.com/politica/cristina-kirchner-parroquia-islamaciel_0_4yJBq8yxW.html

DESPUÉS de la misa, un grupo de curas cantó la marcha peronista. Perfil, Buenos Aires, 15 de mayo de 2017. Actualidad. Recuperado de https://www.perfil.com/noticias/actualidad/curas-celebraron-lamisa-con-la-marcha-peronista.phtml

DOMINELLA, V. Chicos comunes, militantes, mártires. La rememoración de víctimas católicas bahienses del terrorismo de Estado en los homenajes de 2011. Aletheia. Revista de la Maestría en Historia y Memoria de la FaHCE, La Plata, volumen 4, n 7, diciembre de 2013. Disponible en: http://www.aletheia.fahce.unlp.edu.ar/front_page

DONATELLO, L. M. Catolicismo liberacionista y política en la Argentina: de la política insurreccional en los setenta a la resistencia al neoliberalismo en los noventa. AméRica Latina Hoy, 41, pp.77-97, 2005.

DONATELlO, L. M. Catolicismo y Montoneros. Religión, política y desencanto. Buenos Aires: Ediciones Cuadernos Argentinos Manantial, 2010.

DRI, R. Teología y dominación. Buenos Aires: Editorial Roblanco, 1986.

EL VATICANO echó al cura cordobés que apoyó el matrimonio gay. Clarín, Buenos Aires, 12 de abril de 2013. Sociedad. Recuperado de: $\quad$ https://www.clarin.com/sociedad/vaticano-cura-cordobesapoyo-matrimonio_0_Sycm24FiwXg.html 
ENTREGARON el pañuelo blanco al grupo Curas en Opción por los Pobres. Tiempo Argentino, Buenos Aires, 15 de octubre de 2017. Política. Recuperado de https:/www.tiempoar.com.ar/nota/entregaron-elpanuelo-blanco-al-grupo-curas-en-opcion-por-los-pobres

ES UNA CUESTIÓN de salud pública. Página 12, Buenos Aires, 23 de febrero de 2018. Sociedad. Recuperado de: https://www.pagina12. com.ar/97606-es-una-cuestion-de-salud-publica

ESSES, J. M. Murales en la Isla Maciel: cómo un grupo de vecinos revalorizó el barrio con arte. La Nación, Buenos Aires, 13 de noviembre de 2018. Brando. Recuperado de: https:/www.lanacion.com.ar/ lifestyle/murales-isla-maciel-como-grupo-vecinos-revalorizo$\operatorname{nid} 2191228$

FEIERSTEIN, D. Genocidio: del concepto al caso argentino. Revista Puentes numero 18, octubre 2006.

FRANCISCO "Paco" Oliveira, el cura que está a favor de la despenalización del aborto y el preservativo. Infobae, Buenos Aires, 27 de julio de 2018. Política. Recuperado de: https://www.infobae.com/ politica/2018/07/27/francisco-paco-oliveira-el-cura-que-esta-afavor-de-la-despenalizacion-del-aborto-y-el-preservativo/

GIMÉNEZ BÉLIVEAU, V. Católicos militantes. Sujeto, comunidad e institución en la Argentina. Buenos Aires: Eudeba, 2016.

GRUZINSKI, S. La guerra de las imágenes. De Cristóbal Colón a "Blade Runner” (1492-2019). México: Fondo de Cultura Económica, 1994.

HALBWACHS, M. La memoria colectiva, Zaragoza, Prensas Universitarias de Zaragoza, 2004.

HERVIEU-LÉGER, D. La religión, hilo de memoria. Barcelona: Herder Editorial, 2005.

HOMENAJE a los Curas. Página 12, Buenos Aires, 15 de octubre de 2017. El país. Recuperado de https://www.pagina12.com.ar/69319homenaje-a-los-curas

JELIN, E. Los trabajos de la memoria. Madrid: Siglo xxi editores, 2002.

JELIN, E. Memoria y democracia. Una relación incierta. Politica / Revista de ciencia política, vol.51, No2, pp.129-144, Santiago de Chile, 2013.

LÖWY, M. Guerra de dioses. Religión y politica en América Latina. México: Siglo xxi, 1999.

MALLIMACI, F. El catolicismo argentino desde el liberalismo integral a la hegemonía militar. En: 500 años de cristianismo en Argentina, 
Pedagogía de los mártires, comunidades militantes católicas y territorio: el caso de la Isla Maciel, Buenos Aires, Argentina (2016-2019).

Buenos Aires, Centro Nueva Tierra, 1992, pp. 197-365.

MALLIMACI, F. y GIMÉNEZ BÉLIVEAU, V. Creencias e increencia en el Cono Sur de América: Entre la religiosidad difusa, la pluralización del campo religioso y las relaciones con lo público y lo político. Revista argentina de sociología, 5(9), 44-63. 2007.

MAYOL, A., HABEGGER, N. y ARMADA, A. Los católicos Posconciliares en la Argentina. Buenos Aires: Editorial Galerna, 1970.

MIGNONE, E. Iglesia y dictadura. Buenos Aires: Editorial de la Universidad Nacional de Quilmes, 1999.

MUGICA, C. Peronismo y cristianismo. Buenos Aires: Merlín, 1973.

OBREGÓN, M. Entre la cruz y la espada. La Iglesia católica durante los primeros años del "Proceso". Buenos Aires: Universidad Nacional de Quilmes, 2005.

PIETO, S. y LOTITO, O. Jóvenes militantes de la "pastoral villera" en la Villa 21-24-Zabaleta: una aproximación sobre las percepciones y representaciones en torno del Estado. Sociedad y Religión: Sociología, Antropología e Historia de la Religión en el Cono Sur, vol. XXII, núm. 38, pp. 44-76. Buenos Aires: Centro de Estudios e Investigaciones Laborales, 2012.

PREMAT, S. Curas villeros. De Mugica al padre Pepe. Historias de lucha y esperanza. Buenos Aires: Editorial Sudamericana, 2010.

RICOEUR, P. La memoria ejercida: uso y abuso. En: La memoria, la historia, el olvido. Fondo de cultura económica. México, 2000, pp.81-123.

ROUSSO, H. Para una historia de la memoria colectiva: El post-Vichy. Aletheia, 3(5). 2012. Disponible en Memoria Académica: http:// www.memoria.fahce.unlp.edu.ar/art_revistas/pr.5463/pr.5463.pdf Accedido en enero 2019.

RUIZ-TAGLE, D. y TOLEDO JOFRÉ, I. Del uso pedagógico de lugares de memoria. Estudios Pedagógicos, Valdivia, XXXV, No 1: 199-220, 2009.

SAN JULIÁN, D. De pasiones y apasionados, los homenajes al grupo de "los 12" en la Iglesia de la Santa Cruz. 2017. Ponencia, ix Jornadas de Ciencias Sociales y Religión. Programa Sociedad, Cultura y Religión del CEIL-CONICET. Universidad de Buenos Aires: Buenos Aires.

TAYLOR, D. El espectáculo de la memoria, trauma, performance y política. Teatro Del Sur, 15, pp. 33-40, 2000. 
TOURIS, C. Sociabilidad e identidad político-religiosa de los grupos católicos tercermundistas en la Argentina (1966-1976). En: Moreyra, Beatriz y Mallo, Silvia (edit.), Miradas sobre la historia social argentina en los comienzos del siglo XXI. Centro de Estudios Históricos "Prof. Carlos Segreti". Córdoba-La Plata: CEHAC, FaHCE-UNLP, 2008.

URANGA, W. Denuncia contra el nuevo párroco de Isla Maciel. Página 12, Buenos Aires, 16 de febrero de 2019. El país. Recuperado de: https://www.pagina12.com.ar/175439-denuncia-contra-el-nuevoparroco-de-isla-maciel

VALENSI, L. Autores de la memoria, guardianes del recuerdo, medios nemotécnicos. Como perdura el recuerdo de los grandes acontecimientos. Ayer, No. 32, pp. 57-68, Memoria e historia, 1998.

VECCHIOLI, V. y MARTINELLI LEAL, E. El activismo de las víctimas en contextos represivos y democráticos. Lecturas cruzadas. Papeles del CEIC, vol. 2017/1, pp.1-11, presentación, CEIC (Centro de Estudios sobre la Identidad Colectiva), UPV/EHU Presss, 2017.

ZANATTA, L. Del Estado liberal a la nación católica. Iglesia y ejército en los orígenes del peronismo. 1930-1943. Buenos Aires: Universidad Nacional de Quilmes, 1996. 